Artículo de Fondo

\title{
UNA ARQUITECTURA DEL LENGUAJE APLICADA A PROBLEMÁTICAS INSTITUCIONALES DE GESTIÓN PÚBLICA. EL PLAN FÉNIXY UN DISCURSO DEL PRESIDENTE KIRCHNER
}

\section{Brian Alejandro Thomson}

Arquitecto, UBA, 1962, Argentina; “Master” y MRTPI en Desarrollo Urbano y Regional, Birmingham City University, Inglaterra, 1965; profesor Titular de la Universidad Nacional del Nordeste, 1966-1972; gerente de Proyecto de la OEA “Paraná Control de Erosión”, Brasil, 1973-1974; director de la Carrera de Geografía de la UBA, 1974; director del Instituto de Servicios para el Ordenamiento Territorial, Rectorado, UBA, 1974; consultor FLACSO, UNEP, UNESCO, FAO, 1975-1976; investigador visitante del Instituto de Ciencias Sociales de La Haya, Holanda, 1976; funcionario de UNESCO, París, 1977; funcionario de OEA, Washington, jefe de la División Caribe Anglófono del Departamento de Desarrollo Regional y Medio Ambiente 1978-1985; subsecretario de Reforma Administrativa, Secretaría de la Función Pública, Gobierno Nacional, presidente Alfonsín, 1986-1989, Argentina; funcionario del Banco Interamericano de Desarrollo (BID), como jefe de la División de Metodología de Proyectos y Jefe de la División de Evaluación Corporativa, Washington, 1990-1999. Actualmente consultor en metodologías de diseño, gerencia y evaluación de proyectos de desarrollo. Socio de la empresa consultora "Claro Associates" www.claroassociates.com, residente en Bethesda, Maryland, USA. Correos electrónicos: brian.a.thomson@verizon.net; bthomson@claroassociates.com; richarby@hotmail.com. 


\section{Resumen}

En mi pasado profesional, a partir de 1978 me encontré inmerso en ámbitos institucionales donde primaba un uso pertinazmente "suelto" del lenguaje, que oscilaba entre la ofuscación y la metáfora disolvente. Mi confrontación con estas prácticas lingüísticas durante mis años de funcionario de organismos internacionales y nacionales me llevó a ocuparme de tratar de encontrar caminos estructurantes que transformaran al lenguaje proyectual metaforizado, común a las instituciones proyectoras, en un lenguaje ético y ejecutivo. Resumí algunos de los resultados de mi búsqueda en un artículo publicado en Cuaderno Urbano N. ${ }^{\circ} 6$ (2007). En esta publicación las experiencias más estrictamente institucionales quedaron en un segundo plano. El presente trabajo se dirige ahora a rescatar dos casos, como ejemplos de una serie de casos de "arquitectura institucional" que desarrollé durante mis actividades profesionales. Los dos casos pretenden demostrar la aplicación de la "metodología dialógica" (WITTGENSTEIN/BAKHTIN) a dimensiones institucionales cuya esencia es la organización de respuestas a problemáticas sociales a través de una arquitectura del lenguaje. Quiero así demostrar la utilidad del método dialógico para domar los excesos lingüísticos de propuestas técnico/políticas que no llegan a fruición porque no parten de una metodología para ordenar política y administrativamente sus ideas.

Palabras clave:

Marco lógico, método dialógico, crisis argentina.

\section{Summary}

During my past professional activities, since 1978, I became immersed in institutional environments where language was used in an opinionated way which oscillated between obfuscation and licentious metaphors. Confronting these linguistic practices during my years as a senior international and national civil servant, led me to search for ways to transform this project design language, dominated by metaphors, common to these project designing institutions, and transform it into an ethical and executive narrative. I summarized many results of my experiences in an article published in Cuaderno Urbano $\mathrm{N}^{\circ} 6$, in which their strictly institutional aspects were only adumbrated. This current paper is directed to recovering two cases, as examples of the use of a "dialogical method" (WITTGENSTEIN/BAKHTIN) applied to institutional dimensions, whose essence is the organization of responses to social needs through the architecture of language. I try to demonstrate the usefulness of this dialogical method to control the linguistic excesses of technical/political proposals which do not come to fruition because they do not originate in a methodology that organizes ideas politically and administratively.

Key words:

Logical framework, dialogical method, crisis in Argentina 
Una arquitectura del lenguaje aplicada a problemáticas institucionales de gestión pública.

El Plan Fénix y un discurso del presidente Kirchner

\section{INTRODUCCIÓN}

Cada día se nos "intimida" con más conectividad digital/verbal flatulenta. Por ejemplo, a fines de abril 2013, apareció un "app" para mandar fotos que las borra del Smartphone del receptor en 10 segundos. Esto ocurrió dentro de un campo de twiteo, facebookeo, etc., cuyo $95 \%$ consiste de opiniones superficiales, desinformación y acicateos políticos o propagandísticos. Estamos consecuentemente ahogándonos en un mundo de lenguaje narrativo (hipo e híper) banal que nos aleja del uso socialmente constructivo de nuestras narrativas y nos hunde en la atrogenia. Necesitamos recuperar la capacidad de usar una arquitectura institucional del lenguaje social que podamos aplicar a la comprensión y superación de nuestros problemas. Solo sabiendo usar un apropiado lenguaje institucional podremos transformar la vorágine lingüística, que nos aturde, en significantes y significados que nos permitan usar el lenguaje como instrumento para "hacer" cosas por la vía de la administración de instituciones. Hemos devaluado totalmente el uso del lenguaje poniéndonos al nivel de los lotófagos de Alfred Tennyson (Lord Byron). ${ }^{1}$

Los dos casos que desarrollaré aquí pretenden demostrar la aplicación de la metodología dialógica a dimensiones institucionales a nivel de políticas de estado, cuya esencia es la organización de respuestas a problemáticas sociales a través de una arquitectura del lenguaje. Quiero así demostrar la utilidad del método dialógico para domar los excesos lingüísticos de propuestas técnico/políticas que no llegan a fruición porque no partieron de una metodología para ordenar política y administrativamente sus ideas.

Sin este orden, las ideas se deslizan en la vorágine de las simplezas y también metáforas y otras duplicidades disuasivas lingüísticas cotidianas que nos invaden en todo quehacer proyectual. Me refiero, por ejemplo, a decir "la transparencia del mercado" por "oportunidades privilegiadas"; o decir "empleabilidad del trabajador" o "transparentar el mercado laboral" por "reducción de costos laborales"; o decir "ajuste estructural" por "cambiar las relaciones sociales de producción a favor de la inversión". Frente a estas mentiras, claramente un visionario (hoy nuevamente reconocido), en el campo del crítica de la manipulación discursiva que acabo de señalar, EsPINOzA, también es pertinente a nuestro tema. Distinguió entre pensamientos (y obviamente sus expresiones lingüísticas) "inadecuados" y "adecuados". Los primeros no nos indican su proceso de producción, su causa. Los segundos se caracterizan precisamente por hacerlo. En este sentido, podríamos derivar la noción de que un proyecto "adecuado" es aquel que nos describe cómo una determinada realidad debe ser producida porque no solo nos representa la genealogía de sus elementos constitutivos, sino también nos indica cómo tal proyecto puede ser alterado y adaptado a la realidad cambiante porque nos describe los eventos cotidianos y prácticos de su proceso de producción. Ello requiere que el proceso de producción de un proyecto
1- "Los Lotófagos", poema de Alfred Tennyson, (Primer Barón Tennyson), publicado en 1832. El poema describe a un grupo de marineros náufragos que en el sitio donde encallan encuentran lotos. Comen sus flores y frutas que alteran su vida consciente y llevan a que se aislen del mundo externo. 
"adecuado" también sea "adecuado", es decir, dialógico. Si no, lo que tendremos es un "producto proyecto" desarticulado que, por esa misma esencia, en vez de poder ser un instrumento de articulación social (objetivo del desarrollo) se transforma en un instrumento de la desarticulación social.

\section{PLANTEANDO UN CAMINO}

Este trabajo es un intento pragmático de buscar que la verdad y no la mentira, al decir ético de EsPINOZA, se exprese en nuestros proyectos y programas. Como intento pragmático es una reflexión sobre los límites y los horizontes de experiencias concretas. Como búsqueda, no pretende convencer sino invitar a los lectores a considerar concepciones, quizás no ortodoxas, del ser y del quehacer del diseño, ejecución y evaluación de proyectos y programas.

Las ideas que sustentan los ejemplos que desarrollaré emergieron lentamente de mi quehacer profesional en instituciones que llamaré "proyectoras" (IFIs: instituciones financieras internacionales [BID, Banco Mundial], e instituciones gubernamentales de cooperación internacional o de gobierno). Estas realidades institucionales me ubicaron en el campo de la articulación y procesamiento institucional de la relación entre necesidades y soluciones a través del diseño de proyectos y programas. Las dificultades de asegurar calidad de diseño, gestión y evaluación de proyectos y programas me dirigieron a la búsqueda del diseño dentro de un contexto social e institucional, donde encontré en la comunicación lógica un punto de partida, basado en el habla, texto, lenguaje, discurso, de los involucrados en un problema (más o menos sometidos por esquemas de poder), que buscaban posibles soluciones. Inserta, en consecuencia, en el campo de lo institucional, la búsqueda que describo aquí se dirigió hacia el encuentro con lo que inicialmente fue una intuición: una arquitectura del lenguaje que se materializa en general de manera facilista y en el peor de los casos como duplicidad evasiva en el cotidiano de las instituciones. También, como veremos, en uno de los casos que desarrollaré, se puede manifestar con las mejores intenciones, pero sin el necesario corolario de la ejecutividad.

Cabría agregar aquí que durante mis trabajos profesionales desde 1992 hasta la fecha he aplicado el método, que aquí desarrollo en dos casos, en más de treinta ocasiones de desarrollo institucional en temas de gestión pública. Entre estos casos, puedo mencionar: 1) en 1995, el desarrollo de un árbol de problemas urbano/regional para una ciudad media en América Latina, un verdadero vademécum para el desarrollo urbano integrado, en ocasiones lo he llamado el mapa de organización de gestión para un intendente municipal, valiendo más que un tradicional plan para dicha gestión; 2) en 2000 contribuí a aplicar el método al Programa de Modernización de la Gestión Pública del Gobierno Nacional en 
Una arquitectura del lenguaje aplicada a problemáticas institucionales de gestión pública.

El Plan Fénix y un discurso del presidente Kirchner

Argentina (lamentablemente con una crisis monetaria agazapada que finalmente explotó); 3 ) durante la crisis política argentina en su fase 2002, asesoré al Ministerio de Gabinete, durante la gestión del presidente Duhalde, para aplicar el método a la transformación de los problemas identificados por un panel de expertos en una primera aproximación a un árbol de problemas y propuestas de gestión; 4) en 2010 desarrollé un marco lógico sobre posibles políticas de desarrollo para CARIFORUM (agrupación de quince países del Caribe Anglófono y República Dominicana), como base para las discusiones de los dieciséis países miembros en vista de la cooperación técnica ofrecida por la Unión Europea.

Todos estos casos demuestran cómo se puede usar el método del marco lógico, extendido a lo que considero un método dialógico, como instrumento para no solo organizar proyectos y programas de inversión, sino para enfrentar la temática mucho más abstracta y difícil de la construcción y gestión de políticas institucionales.

Los casos elegidos en este trabajo son los más extremos que he desarrollado. En uno de ellos, parto de una propuesta socioeconómica desarrollada en el año 2000 frente a la inminente crisis de 2001 en Argentina; el otro ejemplo se basa en una frase del presidente Kirchner en ocasión de su visita poselectoral a Washington, donde expresó un deseo para una argentina "normal". Al primer caso lo he llamado caso inductivo, ya que parte de ideas seriamente desarrolladas por los miembros del Grupo Fénix, y mi esfuerzo fue tratar de entender mejor sus posibilidades de implementación, en un universo ideal. Al segundo lo he llamado deductivo, porque partí de una frase del presidente y a partir de ella construí un marco lógico donde tomé la frase significativa como fin de una misión de gobierno.

En ambos casos, reitero al lector/la lectora que debe recordar que son ejercicios desarrollados hace más de diez años, y en consecuencia contienen las imperfecciones de su avanzada edad, pero ello no quita su empleo como ejemplos del uso alternativo y más significativo del método que acaba con las mentiras o desvíos que permiten las páginas escritas y los discursos facilistas.

\section{BREVE INTRODUCCIÓN METODOLÓGICA}

Este trabajo y sus casos se basan en el uso de lo que prefiero llamar "método dialógico" (ver mi artículo en Cuaderno Urbano N. ${ }^{\circ} 6$ ) en honor y reconocimiento de las ideas de Mikhail BAHKTin. Llegué a este método como resultado de varios años de experiencias con el uso del marco lógico y un desarrollo adicional de él sobre la base de lecturas de LUDwIG Wittgenstein, BaKhtin y Valentín Volosinov, a los cuales, recientemente, he agregado principios importantes de STEVEN PINKER contenidos en su libro The Language Instinct (El Instinto del Lenguaje). En su trabajo, PINKER propone la existencia de una estructura prelingüística en el cerebro humano que nos predispone a una "gramática universal" (ver 
también las ideas de NoAm CHOMSKy), en la cual la construcción de oraciones simples y complejas se basa en la organización de frases sustantivas y verbales que constituyen árboles que describen todo lo que comunicamos. Árboles sorprendentemente parecidos a los de problemas y soluciones que son usados en el método dialógico.

Dado que el universo al cual se refiere esta introducción metodológica es el de las aplicaciones concretas y directas de la metodología al diseño, gestión y evaluación de las operaciones de tipo político, económico y social, cabe comenzar por marcar la profunda diferencia que existe entre, por ejemplo, conocer lo que es un tablero de ajedrez y saber jugar al ajedrez. Esta misma diferencia es la que existe entre decir que se conoce un instrumento (esencialmente lingüístico), por ejemplo el marco lógico, y entender el método dialógico que alimenta y que le da vida a ese instrumento. En el primer caso se reduce el instrumento a una tabla utilitaria. En el segundo se aplican las reglas lingüísticas de un diálogo lógico, sostenido con otros interlocutores en un proceso creativo verdaderamente participativo. A través de él se construye un discurso común a todos los involucrados, que permite relacionar demandas reales con ofertas de soluciones, también reales, sin cuya consistencia mutua los esfuerzos de acción política, inversión, etc., no solo fracasan, sino además es un esfuerzo "sherlockiano" saber por qué lo hicieron.

Partiendo de la segunda hipótesis "saber jugar al ajedrez", el quid de la cuestión es entonces determinar cómo hacemos para registrar los discursos (textos) sobre identificación de problemas o sobre "propuestas de solución" y transformarlos en "diálogos" dirigidos al asunto serio del financiamiento y ejecución de proyectos y programas con fines políticos. Aunque parezca trivial (pero es tan fundamental como la base de nuestra comunicación, el alfabeto y las palabras que este nos permite construir), estamos hablando de la construcción de sistemas de notación o de registro del diálogo que se hace posible con el método dialógico que aquí propongo: comunicar ideas a través de un proceso que nos lleva a pasar, según BAHKTin, de la heteroglosía, (situación de incomunicación entre las reglas de varios "juegos de lenguaje") a la homoglosía (la buena comunicación entre varios jugadores utilizando un solo sistema de reglas en su juego de lenguaje).

En este esquema, la notación de las demandas, la síntesis de la inducción, o definición del problema, se expresará en un "árbol de problemas", que es esencialmente un sistema de notación lingüístico que parte de las narrativas de los involucrados. La notación de las ofertas o propuestas de solución, la síntesis de la deducción, se expresará en el llamado "marco lógico", sistema de notación lingüística de la esencial etapa deductiva que rescata esas narrativas iniciales en un diseño que reconstruye, en sentido inverso, las cadenas de causa/efecto originarias de los problemas. Así las transforma en cadenas de medios (recursos) y fines (resultados), sin las cuales no existirá la mencionada consistencia mutua entre problemas y soluciones, que llevará al inevitable fracaso de la ejecución de la propuesta. 
La efectividad de la aplicación de este principio de "consistencia" entre problemas y soluciones se podrá verificar en la medida en que en los diseños de los proyectos muestren que la necesaria lógica del corazón del negocio de "lo político", el "dimensionamiento para la acción política", no distorsione la lógica implícita del espíritu de este "negocio": la conversación (diálogo lógico) sobre y para el desarrollo socioeconómico, institucional y cultural.

Esta diferencia, entonces, entre conocer un tablero de ajedrez (por ejemplo, el marco lógico) y saber jugar al ajedrez del diálogo (método dialógico) sobre proyectos y su ejecución - que se aplica a un proceso de diálogo estructurado entre lo que en el fondo son demandantes y oferentes de necesidades y recursos sociales - es lo que trato de demostrar y contribuir a aclarar en las reflexiones que justifican los ejercicios que aplico al "Plan Fénix" (versión 2000) y al paradigma que mencionó el presidente Kirchner en un breve discurso en ocasión de su primera visita a Washington, cuando dijo: "Quiero que la Argentina sea un país normal". En el primer caso aplicaré el método de manera inductiva a una formulación explícita de un "plan"; en el segundo caso aplicaré el método de manera deductiva a lo que fue una expresión de deseo, devenido objetivo de una misión, construyendo teóricamente las narrativas de las acciones y sus resultados, para materializar ese deseo.

Dadas las implicancias de partir de tal núcleo conceptual para el uso de nuestro instrumento fundamental de trabajo, el lenguaje y su expresión "conversacional" (el habla y el texto, para realizar el diálogo), es inevitable tener que subir un peldaño más en la escalera de la búsqueda de un asidero para nuestras "conversaciones" con objetivos de inversión y desarrollo. Y, llegados a ese peldaño podemos otear y reconocer otra aparente trivialidad: que todo grupo proposicional político, como toda institución humana, debe ser ante todo una "comunidad lingüística".

Aquí nos encontramos con lo que propongo como el paradigma central de mis reflexiones, que es intentar demostrar, a través de dos ejercicios, la posibilidad de un método más efectivo para relacionar mejor propuestas científicas y técnicas con la acción política, o sea, nuestro "lenguaje" con nuestras "acciones".

Ello se materializa en la noción de asumir que toda "comunidad lingüística" que quiere transformar sus ideas en realidades se comunica (conversa, dialoga) con otras "comunidades lingüísticas", para lo cual es esencial plantearnos cómo se comunican entre sí las diversas comunidades lingüísticas de una nación para lograr ejecutar las acciones políticas deseadas. Es decir, cómo sortear la encrucijada de la Torre de Babel implícita en la acción democrática. La derecha no tiene este problema, ya que condiciona — sobre todo hoy — el lenguaje de manera de servir a sus objetivos coercitivos, con apariencias democráticas.

En realidad, entonces, este método abre las puertas a ejercicios de ordenamiento de los resultados de "conversaciones" enmarcadas en propuestas de políticas, dirigidas a trans- 
parentar mejor la lógica del diálogo sobre los problemas y la ejecución de las propuestas emergentes. Como he señalado, la inspiración principal de estas ideas radica en las propuestas lingüísticas sobre "juegos de lenguajes" de Ludwig WitTGEnstein.

Para los que todavía creen en ciertos valores que hoy (esto escrito en 2001) corren el serio riesgo de ser barridos por la negatividad entendible de mis compatriotas, quiero agregar que WitTGENStein no provee solo un atajo lógico. Este filosofo colocó al lenguaje como un "juego" muy serio que solo se realiza en una comunidad, o "forma de vida", partiendo de la idea de indagar la filosofía a través de la gramática, con el objeto de asegurar que los valores éticos de lo que decimos, y en consecuencia hacemos, sean claramente delimitados. En esto, WitTGENSTEIn se inspiró en Karl Kraus (1874-1936), el pensador y periodista austríaco que siempre se dedicó al contenido ético del lenguaje público. En este sentido, mi argumento central es que aunque tuviéramos una varita mágica y pudiéramos cambiar las actuales condiciones políticas, todavía nos quedaría el problema de cuán verdaderos son los textos que generamos y difundimos a la sociedad desde la perspectiva del logro de los objetivos que una ideología progresista del desarrollo se podría plantear. KARL KRAUS criticó a la prensa vienesa por "ahogar a los sustantivos en un mar de adjetivos". Tengamos el cuidado renovado de no hacer lo mismo en nuestra Argentina en crisis de realidades y creencias. Para ello también debemos evitar ahogar los verbos en un mar de adverbios.

Como las matrices y árboles que presentaré en los casos analizados son esencialmente parte de la llamada metodología del marco lógico, he incluido en las siguientes dos páginas versiones básicas del contenido del marco lógico y del árbol de objetivos. Aunque supongo que para la mayoría de los lectores se trata de una metodología básica conocida y usada por todos los organismos multilaterales y agencias nacionales de cooperación, sugiero su breve revisión antes de proseguir, ya que facilitará la comprensión de los dos ejemplos que presento. 
Una arquitectura del lenguaje aplicada a problemáticas institucionales de gestión pública. El Plan Fénix y un discurso del presidente Kirchner

Gráfico 1. Árbol de Objetivos de un Proyecto

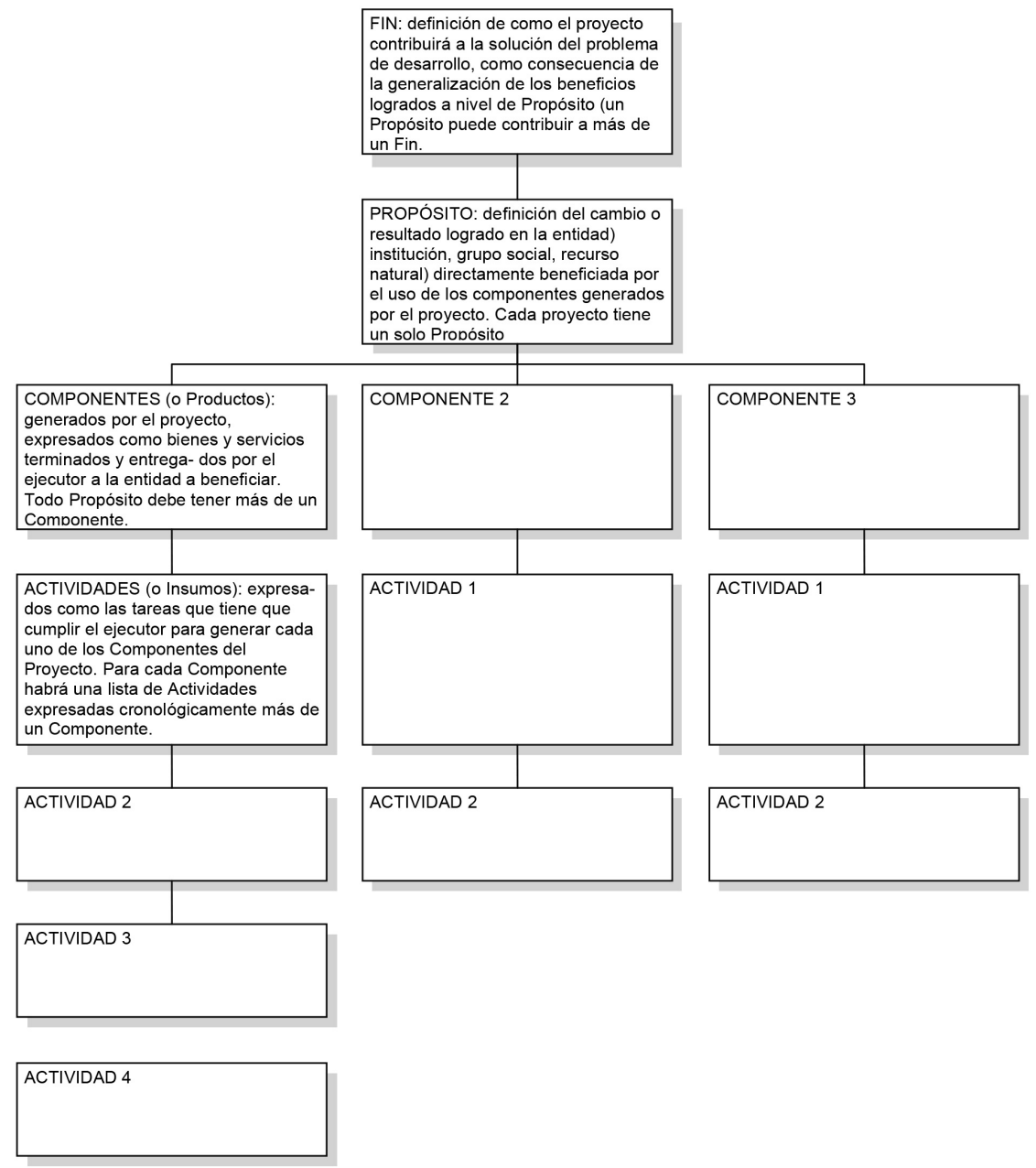

Fuente: Todos los cuadros y gráficos fueron elaborados por el autor 
$\underline{\text { Cuadro } 1}$

\begin{tabular}{|c|c|c|c|}
\hline $\begin{array}{l}\text { RESUMEN NARRATIVO DE } \\
\text { OBJETIVOS }\end{array}$ & $\begin{array}{l}\text { INDICADORES } \\
\text { VERIFICABLES } \\
\text { OBJETIVAMENTE }\end{array}$ & MEDIOS DE VERIFICACIÓN & SUPUESTOS \\
\hline $\begin{array}{l}\text { FIN } \\
\text { Es una definición de cómo el } \\
\text { proyecto o programa } \\
\text { contribuirá a la solución del } \\
\text { problema (o problemas) del } \\
\text { sector. }\end{array}$ & $\begin{array}{l}\text { Los indicadores miden los } \\
\text { resultados de mejora que el } \\
\text { proyecto logrará luego de que } \\
\text { haya estado en } \\
\text { funcionamiento durante una } \\
\text { cantidad significativa de } \\
\text { tiempo. Los indicadores son } \\
\text { específicos en términos de } \\
\text { cantidad, calidad y tiempo. }\end{array}$ & $\begin{array}{l}\text { Los medios de verificación } \\
\text { son las fuentes de } \\
\text { información que un evaluado } \\
\text { puede utilizar para verificar } \\
\text { que los objetivos se lograron. } \\
\text { Pueden incluir material } \\
\text { publicado, inspección visual, } \\
\text { encuestas por muestreo, etc. }\end{array}$ & $\begin{array}{l}\text { Los supuestos indican los } \\
\text { eventos, las condiciones o las } \\
\text { decisiones importantes } \\
\text { necesarias para la } \\
\text { "sostenibilidad" (continuidad } \\
\text { en el tiempo) de los objetivos } \\
\text { del Fin. }\end{array}$ \\
\hline $\begin{array}{l}\text { PROPÓSITO } \\
\text { Es la definición de la } \\
\text { contribución que el proyecto } \\
\text { realizará para el logro del Fin. } \\
\text { Declara lo que se logrará, al } \\
\text { terminar la ejecución. }\end{array}$ & $\begin{array}{l}\text { Los indicadores miden los } \\
\text { resultados que se alcanzarán } \\
\text { al final de la ejecución del } \\
\text { proyecto si el proyecto se } \\
\text { ejecuta en forma exitosa. } \\
\text { Cada indicador especifica } \\
\text { cantidad, calidad y tiempo de } \\
\text { los resultados por alcanzar. }\end{array}$ & $\begin{array}{l}\text { Los medios de verificación } \\
\text { son las fuentes que el } \\
\text { ejecutor y el evaluador } \\
\text { pueden consultar para ver si } \\
\text { los objetivos se están } \\
\text { logrando. Pueden indicar } \\
\text { que existe un problema y } \\
\text { sugieren la necesidad de } \\
\text { cambios en los componentes } \\
\text { del proyecto. Pueden incluir } \\
\text { material publicado, } \\
\text { inspección visual, encuestas } \\
\text { por muestreo. }\end{array}$ & $\begin{array}{l}\text { Los supuestos indican los } \\
\text { acontecimientos, las } \\
\text { condiciones o las decisiones } \\
\text { que están fuera del control } \\
\text { del gerente de proyecto } \\
\text { (riesgos) que tienen que } \\
\text { ocurrir para que el proyecto } \\
\text { logre el fin. }\end{array}$ \\
\hline $\begin{array}{l}\text { COMPONENTES } \\
\text { Son obras, servicios, } \\
\text { asistencia técnica y } \\
\text { capacitación que se requiere } \\
\text { que complete el ejecutor del } \\
\text { proyecto de acuerdo con el } \\
\text { contrato. Estos deben } \\
\text { expresarse en trabajo } \\
\text { terminado (sistemas } \\
\text { instalados, gente capacitada, } \\
\text { etc.) }\end{array}$ & $\begin{array}{l}\text { Los indicadores son } \\
\text { descripciones breves, pero } \\
\text { claras de cada uno de los } \\
\text { Componentes que tiene que } \\
\text { terminarse durante la } \\
\text { ejecución. Cada uno debe } \\
\text { especificar cantidad, calidad y } \\
\text { oportunidad de las obras, } \\
\text { servicios, etc., que deberán } \\
\text { entregarse. }\end{array}$ & $\begin{array}{l}\text { Este casillero indica dónde el } \\
\text { evaluador puede encontrar } \\
\text { las fuentes de información } \\
\text { para verificar que las cosas } \\
\text { que han sido contratadas han } \\
\text { sido entregadas. Las fuentes } \\
\text { pueden incluir inspección del } \\
\text { sitio, los informes del auditor, } \\
\text { etc. }\end{array}$ & $\begin{array}{l}\text { Los supuestos son los } \\
\text { acontecimientos, las } \\
\text { condiciones o las decisiones } \\
\text { (fuera del control del gerente } \\
\text { de proyecto) que tienen que } \\
\text { ocurrir para que los } \\
\text { componentes del proyecto } \\
\text { alcancen el Propósito para el } \\
\text { cual se llevaron a cabo. }\end{array}$ \\
\hline $\begin{array}{l}\text { ACTIVIDADES (TAREAS) } \\
\text { Estas Actividades son las } \\
\text { tareas que el ejecutor tiene } \\
\text { que cumplir para completar } \\
\text { cada uno de los componentes } \\
\text { del proyecto. Se hace una } \\
\text { lista de actividades en orden } \\
\text { cronológico para cada } \\
\text { componente. Las actividades } \\
\text { son aquellas que realizará la } \\
\text { unidad ejecutora. }\end{array}$ & $\begin{array}{l}\text { Este casillero contiene el } \\
\text { presupuesto para cada } \\
\text { Componente a ser entregado } \\
\text { en el proyecto. }\end{array}$ & $\begin{array}{l}\text { Este casillero indica dónde un } \\
\text { evaluador puede obtener } \\
\text { información para verificar si el } \\
\text { presupuesto se gastó como } \\
\text { estaba planeado. } \\
\text { Normalmente constituye el } \\
\text { registro contable de la unidad } \\
\text { ejecutora. }\end{array}$ & $\begin{array}{l}\text { Los supuestos son los } \\
\text { acontecimientos, condiciones } \\
\text { o decisiones (fuera del } \\
\text { control del gerente de } \\
\text { proyecto) que tienen que } \\
\text { suceder para completar los } \\
\text { Componentes de proyecto. }\end{array}$ \\
\hline
\end{tabular}


Una arquitectura del lenguaje aplicada a problemáticas institucionales de gestión pública.

El Plan Fénix y un discurso del presidente Kirchner

\section{UN CASO INDUCTIVO: TRANSFORMACIÓN DE UNA NARRATIVA EN UN PROYECTO. UN "HACIA” DEL "PLAN FÉNIX”}

Este es un ejercicio que realicé en mayo 2002 y revisé en septiembre de 2002. Obviamente refleja el "zeitgeist" del momento que se vivía en Argentina, ante el cual el Grupo Fénix había publicado su propuesta económica para el país, el conocido Plan Fénix.

Dentro de mi búsqueda de trasformación de narrativas descriptivas en narrativas operativas, me pareció un excelente y oportuno ejemplo para desarrollar mis ideas al respecto. La narrativa del caso que expongo abajo debe entonces leerse en el contexto de 2002.

\subsection{Enfoque conceptual}

Las ideas que aquí expongo (originalmente escritas en 2002) están dirigidas a todos aquellos que todavía creen que existen alternativas fuera del sistema que nos ha destruido el país, y que esas alternativas merecen una exposición ilustrativa que demuestre la posibilidad de estructurar un camino operativo que contribuya a conectar, por la vía de lo político, propuestas con realidades. Dominados por los "discursos", buenos pero inefectivos y malos pero efectivos (según los intereses de sus beneficiarios), desde los días de la oscuridad del Proceso, creo que cabe retomar el discurso bueno pero darle dientes operativos, dientes que permitan diseñar e intentar estructurar ejecutivamente el Estado y las relaciones sociales necesarias para salir de la aporía actual del "que se vayan todos" que hoy domina, justificadamente, desde lo subjetivo, al tejido social, y contribuir a entrar en una estrategia y un plan que muestren no solo un camino, sino cómo recorrerlo.

En tal sentido, asumo a las propuestas del denominado "Plan Fénix" como una base conceptual y propositiva para ensayar el intento ilustrativo que propongo. Para ello pretendo abordar desde un enfoque estratégico y ejecutivo las propuestas centrales de este importante documento. Sin embargo, (en 2001) escribo estas líneas con dos grandes dudas. En primer lugar no sé si esta tarea de intentar ligar propuestas con acción política por la vía de un tamiz operativo de las primeras para ordenarlas hacia las segundas ya ha sido elaborada. Si fuera el caso, pido a los involucrados tomar mis propias elaboraciones como una hipótesis adicional. En segundo lugar, uno se pregunta de dónde saldrá tal capacidad de acción política, y a efectos de pecar de panglosiano, sugiero que la estructura expositiva que propongo aquí podría contribuir a que esa nueva capacidad pueda percibir la posibilidad de una nueva dirección de lo político que le permita pasar de la ideología discursiva a la administración de sus postulados en la práctica cotidiana de una sociedad en crisis.

En este sentido, este trabajo es entonces un primer borrador que intenta traducir el lenguaje de las excelentes propuestas efectuadas en el Plan Fénix desde la perspectiva de una lógica ejecutiva, que pretende construir un plano de continuidad entre propuestas y la 
ejecución de políticas. La falta de este plano ha significado una barrera que siempre se ha interpuesto entre aspiraciones y logros sociales.

La coyuntura actual, al contrario, está imponiendo una solución de continuidad entre las viejas formas de hacer política y nuevas formas emergentes de hacerla. Los métodos que aquí aplico pretenden mostrar una posibilidad de abrir este camino Es decir, efectuar una primera aproximación hacia un ejercicio para transformar propuestas en procesos de generación de resultados. Los ejes del proceso de traducción que intentaré son: 1) la distinción entre las categorías de los modos de ser textuales (y reales) de las propuestas; 2) la asignación de un lugar a los textos constituyentes en una cadena de procesos de generación de resultados esperados; 3) la distinción entre textos desde el punto de vista de su valor descriptivo respecto de esos resultados y de las condiciones externas para su logro y 4) sugerir la aplicación de una conocida técnica de notación que permita "poner cada texto propositivo en su lugar", en una cadena ejecutiva.

\section{1) $($ ("a=a, pero a no=b")}

El primer eje se resume en la idea de que no se pueden mezclar en el mismo nivel lógico textos que expresan modos de ser distintos de un objeto de operación ejecutiva. Es decir, por ejemplo, el mismo objeto "IVA" se expresa como un modo de ser visto como estudio de reforma, como otro modo de ser visto como propuesta de ley, como otro modo de ser visto como cuerpo de normas administrativas y como otro visto como efectos sociales y económicos producidos por la aplicación de dicho cuerpo de normas.

\section{2) ("a y b no pueden ocupar el mismo tiempo ni espacio"; y "a es causa de b")}

El segundo eje intenta determinar, una vez establecidas las distinciones entre los modos de ser de las categorías textuales, el orden causal de estas en un proceso de producción de resultados. La forma más simple de ordenar estas categorías textuales en un proceso ejecutivo es distinguir procesos (actividades e insumos), productos (bienes y servicios generados por dichos procesos), logros inmediatos (efectos de uso del producto por parte de un sujeto social o efectos sobre un objeto cuando el producto es aplicado a aquel) y logros mediatos (efectos sociales y económicos resultantes de la generalización de los logros mediatos en el resto del cuerpo social). Para simplificar, llamaré a estos cuatro estadios causales actividades, componentes, propósitos y fines. 
Lo esencial de estos cuatro estadios es que se dividen en dos clases adicionales. Aquellos cuyo proceso de acción, producción y aplicación es controlable por parte del "ejecutivo": actividades y componentes, y aquellas sobre cuyo proceso de generación el "ejecutivo" no tiene control directo. De allí la importancia, como veremos, de los "supuestos" (la inversa del riesgo, lo que se necesita que ocurra para garantizar el éxito del proyecto) mencionados en el eje siguiente. La definición y la capacidad de "sortear" el no cumplimiento de estos supuestos es la esencia de la gestión política.

\section{3) ("a pasa a ser b solo si se cumple: $[\mathrm{a} 1+\mathrm{a} 2+\mathrm{a} 3] \mathrm{x}$ a4")}

El tercer eje clasificatorio se aplica a los cuatro niveles establecidos en el segundo eje. Así en cada nivel de objetivos, con el objeto de efectivizar los principios de ejecutividad, transparencia y responsabilidad que requiere una nueva práctica política, se deberán abrir cuatro dimensiones descriptivas del modo de ser respectivo (causa) que detallan su paso hacia otro modo de ser (efecto). La primera es un resumen textual que describe el proceso, objeto o efecto que se espera materializar en cada nivel. La segunda es una definición de los indicadores que se usarán para definir el intervalo de logro esperado; la tercera es la definición de las fuentes de información que se usarán para verificar dichos indicadores y la cuarta es la especificación de las condiciones externas a la acción ejecutiva descrita, que deben cumplirse para garantizar que los logros de un nivel de modo de ser puedan pasar, categorialmente, a expresarse en el nivel inmediato superior de la cadena de causa-efecto que inevitablemente define toda acción de gestión política.

\section{4) (a,b,c,d,e,f,g,h,... x,y,z; pentagrama; signos algebraicos, etc.)}

A los efectos de garantizar la buscada operacionabilidad de este ordenamiento textual, debe existir un cuarto eje, o sea, una técnica de notación que genere mensajes ejecutivos unívocos y verificables. Para este ejercicio usaré dos tipos de técnicas notación: la estructura o árbol de objetivos y el marco lógico. Estos sistemas de notación son solo una parte de un conjunto de sistemas de notación aplicables en una metodología dialógica.

\section{a) Estructura de objetivos (ver figura 2)}

La "estructura de objetivos" es el instrumento de notación de los diferentes niveles de modos de ser de las entidades identificadas en los textos de propuestas, y constituye el primer paso para verificar la consistencia categorial y causal de aquellos. Es decir, una 
síntesis de los primeros dos ejes que señalé. Dentro de la lógica del sistema de notación de "estructura de objetivos", también se deben cumplir ciertas reglas de la propuesta técnica de notación. La regla principal, que tiene que ver con la esencial discriminación de objetivos, se establece a nivel del llamado propósito, o sea, el resultado de haberse usado un producto expresado en un cambio positivo del objeto de cambio es en realidad el título de un proyecto, ya que el próximo nivel inmediato superior del marco lógico (el fin) solo se puede lograr si se cumplen los postulados del párrafo tres. Para garantizar el orden ejecutivo a quien esté a cargo, o a la institución que esté a cargo de la ejecución del "proyecto", y evitar la toma de decisiones "en conflicto", cada proyecto debe tener un solo propósito. Si un proceso de logro de cambios necesarios para resolver un problema requiere de más de uno de estos resultados o propósitos, se tratará de más de un proyecto. En tal caso, el logro inmediato superior de un conjunto de proyectos es un programa, o sea, el resultado logrado como consecuencia del efectivo logro de los propósitos de todos los proyectos del mismo, más el cumplimiento de los supuestos del caso. Similarmente un conjunto de programas constituye una estrategia y un conjunto de estrategias constituyen una misión. Así una política de gobierno sería una misión. Por ejemplo, lograr una mejora del nivel de vida de la población. Esta misión estaría compuesta por varias estrategias, una de las cuales puede ser el aumento de saldos agropecuarios exportables elaborados, otra puede ser mejorar los niveles educativos, etc. La estrategia de saldos exportables puede consistir en varios programas. Por ejemplo, aumento de la producción de carne de calidad, aumento de calidad y cantidad de productos frutales, aumento de la inversión agroindustrial, etc. A su vez, cada uno de estos programas estaría compuesto por una cantidad de proyectos, y estos a su vez, por componentes y los componentes, por actividades.

Es claro que lo que estoy describiendo es solo la primera pero más importante aproximación a un proceso de planeamiento. Esta aproximación luego será objeto de dimensionamientos técnicos, sociales, económicos, ambientales, etc. Todo esto deberá ser sometido a las clásicas técnicas de programación y presupuesto, ninguna de las cuales es objeto de este primer corte que ensayo aquí, a modo de ejemplo.

\section{b) Marco lógico (ver figura 1)}

Este es el instrumento de notación de los ejes tercero y cuarto.

En los tres ejercicios que siguen, tomaré el texto introductorio presentado en el sitio http://www.econ.uba.ar/www/destacados/fenix.htm (2000) y efectuaré un primer corte aplicando los referidos sistemas de notación. Este texto tiene tres partes proposicionales muy claras. Para el ejercicio 1, tomaré la sección denominada "Condiciones para el de- 
Una arquitectura del lenguaje aplicada a problemáticas institucionales de gestión pública.

El Plan Fénix y un discurso del presidente Kirchner

sarrollo económico y social"; para el ejercicio 2, tomaré la sección "Medidas de Corto Plazo" y para el ejercicio 3, haré lo propio con la sección llamada "Medidas de mediano y largo plazo".

Ciertamente, antes de proceder, debo aclarar un problema metodológico previo. Los ejercicios que desarrollaré se limitan a una transposición de estos textos con el objeto de verificar su lógica ejecutiva implícita. En este sentido, el ejercicio que propongo no es justo ni imparcial porque los textos originales no se generaron tomando en cuenta esta posibilidad. Por ello es importante recordar que mi objetivo no se dirige a la calidad de las propuestas en sí, sino a su ordenamiento en vista de la acción política.

En este sentido, también desde la perspectiva dialógica, los ejercicios que siguen padecen de una falla de origen. Ello porque no estamos partiendo del árbol o estructura de problemas que debe ser previo al ordenamiento causal de un árbol de objetivos. El árbol de problemas es en realidad un ejercicio dialógico pendiente, que debería realizarse en el seno de la "comunidad Fénix" una vez que se quiera pasar a la formulación de un esquema operativo político. Si no se hace esto, estaremos intentando resolver encadenamientos de medios y fines sin haber definido primero los encadenamientos causales de los problemas que hay que resolver. Esta trampa es típica de la mayoría de los proyectos con financiamiento internacional. Se trata de soluciones sin identidad lógica con los problemas reales para resolver. Su identidad lógica es en realidad con los bienes y servicios cuya producción será objeto de los "contratos" del proyecto, no con los resultados sociales y económicos resultantes de dichos contratos.

\subsection{Análisis general de los tres textos}

Ver los textos en secciones 4.3.1, 4.3.2 y 4.3.3. 
Cuadro 2. Categorías de objetivos expresadas a nivel de estrategia en cada texto

\begin{tabular}{|c|c|c|}
\hline Texto 1 & Texto 2 & Texto 3 \\
\hline $\begin{array}{l}\text { 1. Estabilidad institucional y } \\
\text { política }\end{array}$ & & $\begin{array}{l}\text { 11a. Reformas institucionales y políticas } \\
\text { 13. Nueva coalición social }\left({ }^{\star}\right)\end{array}$ \\
\hline 2. Aumento del empleo & $\begin{array}{l}\text { 1. Actividades empleo } \\
\text { intensivas promovidas }\end{array}$ & $\begin{array}{l}\text { 3. Mejora cantidad y calidad } \\
\text { de empleo }\end{array}$ \\
\hline $\begin{array}{l}\text { 3. Mercados eficientes y } \\
\text { competitivos }\end{array}$ & & 12. Patrones de comportamiento empresario \\
\hline $\begin{array}{l}\text { 4. Equilibrios } \\
\text { macroeconómicos sólidos }\end{array}$ & $\begin{array}{l}\text { 2. Estado con } \\
\text { disponibilidades fiscales }\end{array}$ & $\begin{array}{l}\text { 1. Deuda pública reestructurada } \\
\text { 2. Programa nacional de reconversión de economias del } \\
\text { interior } \\
\text { 9. Política fiscal reestructurada }\end{array}$ \\
\hline $\begin{array}{l}\text { 5. Producción nacional } \\
\text { competitiva }\end{array}$ & & $\begin{array}{l}\text { 10a. Aparato productivo argentino competitivo } \\
\text { 5. Política remueve dependencia externa } \\
\text { 7. Valor dinero es equivalente al valor de cambio de } \\
\text { bienes y servicios } \\
\text { 3. Mayor producción alentada } \\
\text { 8. Fuerte perfil en negociaciones multilaterales }\end{array}$ \\
\hline $\begin{array}{l}\text { 6. Cambio tecnológico } \\
\text { incorporado }\end{array}$ & & 10b. Políticas de fomento productivo \\
\hline 7. Estado presente & $\begin{array}{l}\text { 2. Estado con } \\
\text { disponibilidades fiscales (?) } \\
\text { 4. Implantación efectiva } \\
\text { de bienes públicos }\end{array}$ & 11b. Reformas institucionales y políticas \\
\hline $\begin{array}{l}\text { 8. Soberanía monetaria y } \\
\text { cambiaria }\end{array}$ & & 6a. politicas monetarias y crediticias autónomas \\
\hline $\begin{array}{l}\text { 9. Mercados de capitales para } \\
\text { producción y comercio }\end{array}$ & $\begin{array}{l}\text { 3. Sistema financiero } \\
\text { reconvertido }\end{array}$ & 6b. políticas monetarias y crediticias autónomas \\
\hline $\begin{array}{l}10 \text { Concepciones dan origen a } \\
\text { oportunidades del mercado } \\
\text { mundial }\left({ }^{*}\right)\end{array}$ & & \\
\hline
\end{tabular}

(*) Estos objetivos son estrictamente políticos y supuestos de cualquier plan.

Esta especie de "primera tabla de verdad" textual simplificada nos demuestra las siguientes cosas. En primer lugar, que cada texto (1 a 3) contiene un orden de prelación diferente, y dentro de dicho orden hay casos en los que no existen equivalencias entre los diferentes objetivos según los textos. Quizás para ordenar estos textos habría que comenzar por los objetivos del texto 3 y de allí derivar los textos 2 y 1 .

En el caso del texto 2 podría argumentarse que "hay más" dicho, pero el problema es que, como veremos en el ejercicio respectivo, lo "más" está en otro nivel inferior categorial. 
Una arquitectura del lenguaje aplicada a problemáticas institucionales de gestión pública.

El Plan Fénix y un discurso del presidente Kirchner

Esto es evidente si los tres textos se revisan identificando conjunciones gramaticales. Estas usualmente implican que se está describiendo más de un objetivo. También deben buscarse preposiciones o frases preposicionales, las cuales usualmente describen o bien una relación causa/efecto, o una característica del objeto, u objetos, de la oración, sugiriendo que se están describiendo indicadores, actividades, productos, medios de verificación y hasta supuestos. Hay una gran cantidad de información en las propuestas, pero tal como está sigue en el nivel del discurso de políticas y no está en el discurso de acciones. Los tres textos en vez de ser partes de un "continuo estratégico", aunque tienen similitudes textuales, parecerían escritos con diferentes objetivos. Estas diferencias textuales se observan más claramente cuando se transponen a un sistema de notación sistemático, como el que desarrollaré.

\subsection{Los ejercicios y los textos de referencia}

A continuación transcribo los textos que utilizaré, sobre la base de la versión en web del “texto Fénix" (2000).

4.3.1. Ejercicio 1

4.3.1.1. Texto Fénix

"Condiciones para el desarrollo económico y social

La teoría y la experiencia histórica y contemporánea de las economías mundial y argentina revelan que el desarrollo económico y la elevación de la calidad de vida requieren el cumplimiento de un conjunto de condiciones.

Estabilidad institucional y politica.

Aumento del empleo e incorporación de la fuerza de trabajo al proceso de crecimiento como requisito de integración del tejido social.

Funcionamiento eficiente y competitivo de los mercados de bienes y servicios, financieros y reales.

Equilibrios macroeconómicos sólidos sobre la base de altas tasas de ahorro interno e inversión, financiamiento genuino del sector público, competitividad internacional, reducción drástica del déficit crónico en la cuenta corriente del balance de pagos. Esto requiere, entre otros requisitos, la búsqueda flexible de precios relativos consistentes con el mantenimiento del poder adquisitivo y el equilibrio externo y una baja tasa de inflación.

Competitividad de la producción nacional, limitando el endeudamiento externo a la capacidad de generación de divisas e inversiones privadas directas en actividades transables que, como mínimo, mantengan en equilibrio sus operaciones en divisas. 
Incorporación generalizada y continua del cambio tecnológico en todo el sistema económico y social, participando de las corrientes dinámicas del comercio internacional compuestas por bienes y servicios altamente diferenciados.

Presencia de un Estado que asegure el desarrollo nacional, la integración social, la equidad distributiva y el bienestar.

Soberanía monetaria, cambiaria y fiscal, dentro del contexto de la economía internacional.

Existencia de mercados de capitales financieros al servicio de la producción y el comercio

Desarrollo de concepciones arraigadas en la realidad nacional y orientadas a dar respuestas a los desafios y oportunidades de la economía mundial. La experiencia histórica y contemporánea es categórica: sólo tienen éxito los países que participan activamente frente a la globalización manteniendo el comando de su propio destino."

\subsubsection{Análisis}

Aplicando las reglas de notación que propongo al primer texto, obtengo el árbol de jerarquía de objetivos y el marco lógico que figuran en las páginas que siguen. El árbol es autoexplicativo. Tal como están formuladas (y sabemos que esta no es la intención), todas las "condiciones" tienen el mismo nivel categorial de forma de ser. Es decir, todas son "a's", ninguna es causa de otra de las diez "condiciones". El árbol no se abre en otros niveles porque no están especificados en el texto. Como las relaciones de causa/efecto nos indican que si ese es el caso ningún objetivo puede ocupar el mismo nivel categorial si es causa de otro(s), es claro que el árbol debería abrirse en una estructura donde algunas de las "condiciones" son causas de otras y por ende en una formulación operativa política, deberían preceder a otras. O bien, si abriéramos cada "objetivo/condición" en los productos o cumplimiento de supuestos que garantizaría su logro, podríamos fijar un orden de prelación operativo/político para ellos.

El marco lógico está obviamente vacío en varias de sus ventanas, porque el texto no pretendió llegar a llenarlas. Sin embargo, al considerar dichas ventanas y tomar por ejemplo los supuestos de cada "programa", podríamos comenzar a develar algunas de las relaciones posibles de causa-efecto entre "condiciones". Lo que el texto sí permite "llenar" son algunas de las ventanas referentes a "indicadores", sin obviamente poder ponerles valores cualitativos, cuantitativos ni temporales . Donde figura un (?), o bien he llenado el vacío con una formulación hipotética, o bien señalo que el texto no incluye la posibilidad de encontrar una noción de indicador. 
$\underline{\text { Una arquitectura del lenguaje aplicada a problemáticas institucionales de gestión pública. }}$

El Plan Fénix y un discurso del presidente Kirchner

En realidad, encontrar las relaciones causales entre categorías de "objetivos-condiciones" no es función de un ejercicio textual analítico ex-post, como el que he efectuado. Encontrar tales relaciones causales y a su vez encontrar las causas de los objetivos formulados, y quizás su mejor formulación, solo resultará de un proceso dialógico entre los productores del "Plan Fénix", cuyo objetivo sería efectuar un análisis de involucrados (dentro del grupo) y formular un árbol de jerarquías de problemas. Esta es quizás la tarea principal que habría que efectuar para lograr una definición más afín con un plan estratégico/político.

\section{Gráfico 3. Jerarquía de Objetivos Ejercicio 1 - Condiciones Fénix}

\section{Cuadro 3. Marco Lógico Ejercicio 1 - Condiciones Fénix}

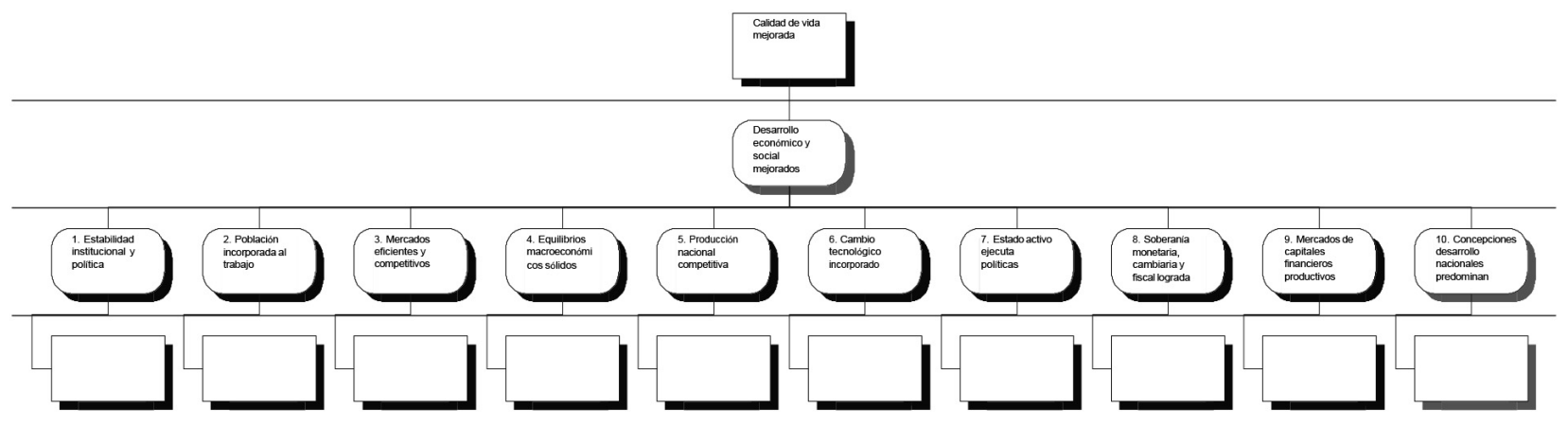




\begin{tabular}{|c|c|c|c|}
\hline Resumen Narrativo & Indicadores & Medios de Verificación & Supuestos \\
\hline \multicolumn{4}{|l|}{ Fin Estrategia } \\
\hline 1 Calidad de vida mejorada (?) & 1.1 & 1.1.1 & 1 \\
\hline \multicolumn{4}{|l|}{ Propósito Estrategia } \\
\hline $\begin{array}{l}\text { Desarrollo económico y } \\
\text { social mejorados }\end{array}$ & 1.1 & 1.1 .1 & 1 \\
\hline \multicolumn{4}{|l|}{ Propósitos Programas } \\
\hline $\begin{array}{l}1 \text { Estabilidad institucional y } \\
\text { política }\end{array}$ & $1.1(?)$ & 1.1.1 & 1 \\
\hline $\begin{array}{ll}2 & \begin{array}{l}\text { Población incorporada al } \\
\text { trabajo }\end{array} \\
\end{array}$ & \begin{tabular}{|ll}
2.1 & Aumenta el empleo \\
2.2 & Integración del tejido social \\
\end{tabular} & \begin{tabular}{|l|}
2.1 .1 \\
2.2 .1 \\
\end{tabular} & \\
\hline $\begin{array}{l}\text { Mercados eficientes y } \\
\text { competitivos }\end{array}$ & 3.1 Bienes $y$ servicios financieros $y$ reales & 3.1 .1 & \\
\hline $\begin{array}{ll}4 & \begin{array}{l}\text { Equilibrios macroeconómicos } \\
\text { sólidos }\end{array}\end{array}$ & $\begin{array}{|ll|}4.1 & \text { Altas tasas de ahorro interno y de inversión } \\
4.2 & \text { Financiamiento genuino del sector publico } \\
4.3 & \text { Competitividad internacional } \\
4.4 & \text { Déficit crónico en cta. cte. de balance de pagos } \\
& \text { reducido } \\
4.5 & \begin{array}{l}\text { Precios relativos consistentes con mantenimiento } \\
\text { poder adquisitivo }\end{array} \\
4.6 & \begin{array}{l}\text { Precios relativos consistentes con equilibrio } \\
\text { externo }\end{array} \\
4.7 & \text { Baja tasa de inflación } \\
\end{array}$ & $\begin{array}{l}4.1 .1 \\
4.2 .1 \\
4.3 .1 \\
4.4 .1 \\
4.5 .1 \\
4.6 .1 \\
4.7 .1\end{array}$ & \\
\hline $\begin{array}{l}5 \text { Producción nacional } \\
\text { competitiva }\end{array}$ & \begin{tabular}{|ll}
5.1 & $\begin{array}{l}\text { Endeudamiento externo limitado a la capacidad } \\
\text { de generación de divisas }\end{array}$ \\
5.2 & $\begin{array}{l}\text { Inversiones privadas directas en actividades } \\
\text { transables equilibran sus operaciones en divisas }\end{array}$ \\
\end{tabular} & $\begin{array}{l}5.1 .1 \\
5.2 .1\end{array}$ & \\
\hline $\begin{array}{l}6 \text { Cambio tecnológico } \\
\text { incorporado }\end{array}$ & $\begin{array}{ll}6.1 & \text { Sistema económico modernizado } \\
6.2 & \text { Sociedad incorpora innovación } \\
6.3 & \text { Generación de bienes y servicios diferenciados } \\
\end{array}$ & $\begin{array}{l}6.1 .1 \\
6.2 .1 \\
6.3 .1 \\
\end{array}$ & \\
\hline $7 \quad$ Estado activo ejecuta políticas & \begin{tabular}{|ll}
7.1 & $\begin{array}{l}\text { Se producen las pre-condiciones } \\
\text { organizacionales y administrativas para el } \\
\text { desarrollo nacional }\end{array}$ \\
7.2 & Integración social \\
7.3 & Equidad distributiva \\
7.4 & Bienestar asegurado \\
\end{tabular} & $\begin{array}{l}7.1 .1 \\
7.2 .1 \\
7.3 .1 \\
7.4 .1 \\
\end{array}$ & \\
\hline 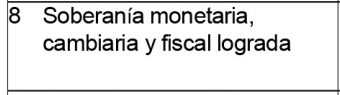 & $\begin{array}{|ll|}8.1 & \text { Moneda independiente } \\
8.2 & \text { Estabilidad cambiaria } \\
8.3 & \text { Equilibrio fiscal } \\
\end{array}$ & $\begin{array}{l}8.1 .1 \\
8.2 .1 \\
8.3 .1 \\
\end{array}$ & \\
\hline $\begin{array}{|ll|}9 & \text { Mercados de capitales } \\
& \text { financieros productivos } \\
\end{array}$ & $\begin{array}{ll}9.1 & \text { Aumenta la inversión productiva } \\
9.2 & \text { Mejoran los servicios comerciales } \\
\end{array}$ & \begin{tabular}{|l|}
9.1 .1 \\
9.2 .1 \\
\end{tabular} & \\
\hline $\begin{array}{l}10 \text { Concepciones desarrollo } \\
\text { nacionales predominan }\end{array}$ & $\begin{array}{l}\text { 10.1 Realidad nacional clarificada (?) } \\
10.2 \text { Desafios y oportunidades de la economía mundial } \\
\text { conocidos (?) } \\
\end{array}$ & $\begin{array}{l}10.1 .1 \\
10.2 .1\end{array}$ & \\
\hline Proyectos de cada Programa & & & \\
\hline 1.1 & 1.1.1 & 1.1.1.1 & 1 \\
\hline (Hasta 10.1) & & & \\
\hline
\end{tabular}


Una arquitectura del lenguaje aplicada a problemáticas institucionales de gestión pública.

El Plan Fénix y un discurso del presidente Kirchner

\subsubsection{Ejercicio 2}

\subsubsection{Texto}

\section{“INSTRUMENTOS DE POLÍTICA}

\section{Medidas de corto plazo}

En lo inmediato es preciso promover (1) actividades empleo-intensivas y socialmente deseables; entre otras, la construcción masiva de viviendas para los sectores de menores ingresos y el refuerzo de la infraestructura básica, las que, al mismo tiempo, contribuirán a sentar las bases fisicas de un nuevo dinamismo económico.

Simultáneamente se deben promover oportunidades de empleo en los servicios a la familia, como por ejemplo, la ampliación de los sistemas de cuidado infantil, cuidado domiciliario de ancianos, promoción de salud en terreno y otras actividades comunitariamente relevantes.

Esto incluye la realización de obras significativas para mejorar las condiciones de vida en los municipios del país y la de obras de infraestructura económica que coadyuven a la integración regional y a las comunicaciones Atlántico-Pacífico.

Se debe establecer un seguro de empleo y formación para los desocupados y una asignación por hijo, así como todas las medidas de promoción y cuidado social necesarias y convenientes para terminar con el drama inaceptable del hambre $y$ la marginación en la Argentina.

Estas medidas requieren una reformulación del sistema financiero local y la disponibilidad de mayores recursos fiscales que se deberán generar mediante las políticas propuestas.

El (2) refuerzo de las disponibilidades fiscales, indispensable para ganar mayor espacio de maniobra para un Estado promotor al servicio del desarrollo y la equidad social, se logrará actuando de manera simultánea sobre los ingresos y los gastos públicos.

Los primeros mejorarán mediante una reforma impositiva global que, en esencia, penalice la riqueza fácil y estimule la orientación de los recursos a la inversión productiva; la reforma debe terminar con los subsidios ocultos en las normas actuales, que cargan su peso sobre los que menos tienen mientras alientan la elusión y permiten la evasión generalizada de los privilegiados.

Los gastos, por su parte, registran un rubro que ya alcanza un peso abusivo e insoportable: los servicios de la deuda. Para contener su impacto negativo, hace 
falta negociar una quita de los montos de capital adeudado, que se complemente con una rebaja de las tasas de interés y un período de gracia de varios años.

Esta opción permite garantizar su pago en el futuro próximo con parte de los frutos del desarrollo que se comenzarán a recoger con la aplicación de los recursos liberados por la política propuesta. Es factible negociar estos cambios porque los resultados van a beneficiar a los mismos inversores, que tendrán así una perspectiva mucho más segura de cobro de sus acreencias en el mediano plazo.

En materia tributaria, se propone aplicar una sobretasa sobre el total del Impuesto a las Ganancias de los contribuyentes que durante cualquiera de los dos últimos ejercicios hayan declarado una renta sujeta a impuesto superior a montos que se establezcan.

Deben revisarse todas las disposiciones de carácter tributario que permitan la evasión, por acción u omisión, tales como los patrimonios societarios que no se reflejan en las declaraciones personales.

Se propone también derogar las exenciones referidas a rentas financieras, primas de emisión y diferencias de valor en cuotas de capital, acciones y títulos valores, así como la incorporación de los dividendos a los ingresos gravados de las personas físicas.

Se debe tender a la disminución progresiva del IVA como tasa general y fijar tasas diferenciales con reducciones sustantivas en los productos de primera necesidad.

La mayor disponibilidad presupuestaria generada por esas mejoras en la recaudación y los gastos no sólo aportará la base indispensable para las políticas recomendadas, sino que asegurará el pleno control público de las herramientas de política económica necesarias para consolidar una nación autónoma y democrática.

La (3) reconversión del sistema financiero exige reducir las tasas de interés, mediante una reducción de los encajes compatible con la vigencia de las normas técnicas, la afirmación del peso como la moneda de intercambio nacional y el tratamiento de la oferta de crédito como un bien público, indispensable para el desarrollo.

La política de recuperación del peso no debe limitarse al sector financiero, sino ampliarse hacia todos los ámbitos del intercambio local como una de las herramientas para construir el peso como una verdadera moneda nacional, capaz de conservar su valor adquisitivo y de representar la soberanía y la convivencia nacional. La utilización de las divisas extranjeras debe recuperar su rol natural de instrumento de intercambio con el resto del mundo.

El cuidado en mantener los equilibrios básicos de la economía permitirá retomar el manejo de la política monetaria, la regulación de la política financiera, 
$\underline{\text { Una arquitectura del lenguaje aplicada a problemáticas institucionales de gestión pública. }}$

El Plan Fénix y un discurso del presidente Kirchner

\begin{abstract}
la atención de la política cambiaria y la (4) implantación efectiva de políticas de provisión adecuada de bienes públicos en los campos de educación, salud, ciencia y técnica, justicia, seguridad y defensa, que han quedado postergadas frente a las falsas prioridades de las politicas previas."
\end{abstract}

\title{
11.3.2.2. Análisis
}

Este segundo texto, medidas de corto plazo, es más complejo que el del ejercicio 1, y por otro lado tiene una estructura categorial más difícil de interpretar. En mi lectura interpreto que se está hablando de una estrategia constituida por cuatro programas, los cuales se describen con diferentes grados de detalle. Este texto parecería estar enfatizando las categorías 2, 4, 7 y 9 del ejercicio 1, pero no es claro por qué.

En las páginas que siguen presento lo que sería el árbol de jerarquía de objetivos a nivel de estrategia, los árboles de objetivos de cada programa y los marcos lógicos de la estrategia y de cada uno de los cuatro programas.

De los árboles se desprenden varios proyectos, pero no es evidente por qué, por ejemplo, habría cinco proyectos del programa 1 y cuál sería el orden de ejecución entre estos proyectos, para lograr el propósito de "actividades empleo intensivas y socialmente deseables promovidas". Lo mismo ocurre con los otros tres programas, siendo el Programa 4 el menos claro. También de estos árboles se desprende la necesidad de definir qué productos (bienes y servicios) habrá que generar, para lograr los propósitos de cada proyecto.

De los marcos lógicos se desprende que en las columnas de supuestos deberían aparecer referencias a las categorías $1,3,8$ y 10 del texto 1 . También se desprende la necesidad de definir indicadores, lo cual implicaría la necesidad no solo de dimensionamiento sino de orden prelación entre proyectos.

Valen aquí los comentarios que efectué al cierre del ejercicio 1.

Gráfico 4. Jerarquía de Objetivos Ejercicio 2 - Estrategia Fénix Corto Plazo 
Cuadro 4. Marco Lógico Ejercicio 2 - Estrategia Fénix Corto Plazo

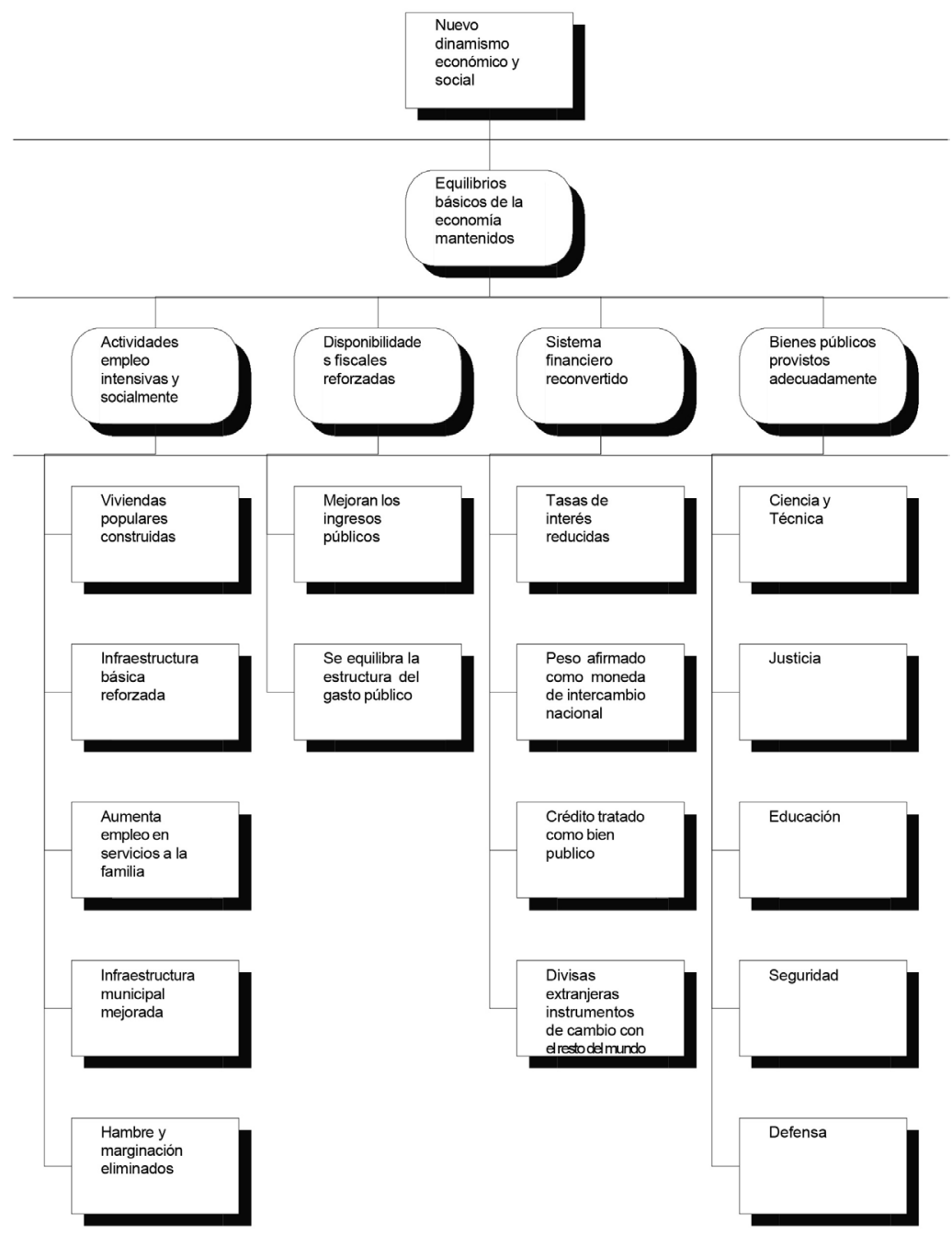


Una arquitectura del lenguaje aplicada a problemáticas institucionales de gestión pública.

El Plan Fénix y un discurso del presidente Kirchner

Gráfico 5. Jerarquía de Objetivos Ejercicio 2 - Programa 1 Estrategia Fénix Corto Plazo

\begin{tabular}{|c|c|c|c|}
\hline Resumen Narrativo & Indicadores & Medios de Verificación & Supuestos \\
\hline \multicolumn{4}{|l|}{ Fin Estrategia } \\
\hline $\begin{array}{l}1 \text { Nuevo dinamismo } \\
\text { económico y social }\end{array}$ & 1.1 & 1.1 .1 & 1 \\
\hline \multicolumn{4}{|l|}{ Propósito Estrategia } \\
\hline $\begin{array}{l}\text { 1. Equilibrios básicos de la } \\
\text { economía mantenidos }\end{array}$ & $\begin{array}{ll}1.1 & \text { Politica monetaria flexible y estable } \\
1.2 & \text { Politica financiera regulada } \\
1.3 & \text { Politica cambiaria regulada } \\
1.4 & \text { Circuito de empleo productivo restablecido(?) }\end{array}$ & $\begin{array}{l}1.1 .1 \\
1.2 .1 \\
1.3 .1 \\
1.4 .1\end{array}$ & 1 \\
\hline \multicolumn{4}{|l|}{ Propósitos Programas } \\
\hline $\begin{array}{l}\text { Actividades empleo } \\
\text { intensivas y socialmente } \\
\text { deseables promovidas }\end{array}$ & 1.1 Reducción de conflictividad social (?) & 1.1.1 & 1 \\
\hline $\begin{array}{ll}2 & \text { Disponibilidades fiscales } \\
\text { reforzadas }\end{array}$ & $\begin{array}{ll}2.1 & \text { Estado con mayor capacidad de maniobra } \\
2.2 & \text { Control público de las herramientas de política } \\
& \text { económica } \\
\end{array}$ & $\begin{array}{l}2.1 .1 \\
2.2 .1\end{array}$ & \\
\hline $\begin{array}{ll}3 & \begin{array}{l}\text { Sistema financiero } \\
\text { reconvertido }\end{array} \\
\end{array}$ & (1) & 3.1 .1 & \\
\hline $\begin{array}{ll}4 & \text { Bienes públicos provistos } \\
\text { adecuadamente }\end{array}$ & 4.1 & 4.1 .1 & \\
\hline \multicolumn{4}{|l|}{ Propósitos Proyectos } \\
\hline $\begin{array}{l}\text { 1.1 Viviendas populares } \\
\text { construidas }\end{array}$ & 1.1.1 Se cubre el déficit primario de viviendas & 1.1.1.1 & \multirow{13}{*}{$\begin{array}{l}\text { A efectos de } \\
\text { este trabajo se } \\
\text { ha omitido la } \\
\text { segunda página } \\
\text { del Marco } \\
\text { Lógico }\end{array}$} \\
\hline $\begin{array}{l}1.2 \text { Infraestructura básica } \\
\text { reforzada }\end{array}$ & $\begin{array}{l}\text { 1.2.1 Integración regional lograda } \\
\text { 1.2.2 Integración Atlántico - Pacífico lograda }\end{array}$ & \begin{tabular}{|l|}
1.2 .1 .1 \\
1.2 .2 .1 \\
\end{tabular} & \\
\hline $\begin{array}{l}\text { 1.3 Aumenta empleo en } \\
\text { servicios a la familia }\end{array}$ & $\begin{array}{l}\text { 1.3.1 Ampliación cuidado infantil } \\
\text { 1.3.2 Ampliación cuidado domiciliario ancianos } \\
\text { 1.3.3 Ampliación provisión salud en terreno }\end{array}$ & $\begin{array}{l}1.3 .1 .1 \\
1.3 .2 .1 \\
1.3 .3 .1 \\
\end{array}$ & \\
\hline $\begin{array}{l}1.4 \text { Infraestructura municipal } \\
\text { mejorada }\end{array}$ & 1.4 .1 & 1.4.1.1 & \\
\hline $\begin{array}{l}1.5 \text { Hambre y marginación } \\
\text { eliminados }\end{array}$ & $\begin{array}{l}\text { 1.5.1 Seguro de empleo establecido } \\
\text { 1.5.2 Asignación por hijo establecida } \\
\text { 1.5.3 Formación de desocupados sistematizada }\end{array}$ & $\begin{array}{l}1.5 .1 .1 \\
1.5 .2 .1 \\
1.5 .3 .1\end{array}$ & \\
\hline $\begin{array}{l}\text { 2.1 Mejoran los ingresos } \\
\text { públicos }\end{array}$ & 2.1 .1 & 2.1.1.1 & \\
\hline $\begin{array}{l}2.2 \text { Se equilibra la estructura del } \\
\text { gasto publico }\end{array}$ & 2.2 .1 & 2.2 .1 .1 & \\
\hline 3.1. Tasas de interés reducidas & 3.1 .1 & 3.1.1.1 & \\
\hline $\begin{array}{l}\text { 3.2. Peso afirmado como } \\
\text { moneda de intercambio } \\
\text { nacional }\end{array}$ & 3.2 .1 & 3.2 .1 .1 & \\
\hline $\begin{array}{l}\text { 3.3 Crédito tratado como bien } \\
\text { publico }\end{array}$ & 3.3 .1 & 3.3.1.1 & \\
\hline $\begin{array}{l}\text { 3.4 Divisas extranjeras } \\
\text { instrumentos de cambio } \\
\text { con el resto del mundo }\end{array}$ & 3.4 .1 & 3.4 .1 .1 & \\
\hline 4.1 Ciencia y Técnica & 4.1 .1 & 4.1.1.1 & \\
\hline 4.2 Justicia & 4.2 .1 & 4.2 .1 .1 & \\
\hline
\end{tabular}

Cuaderno Urbano. Espacio, Cultura, Sociedad - Vol. 15 - N.ํ 15 (Noviembre de 2013)- Pp. 137-191 - ISNN1666-6186 
Cuadro 5. Marco Lógico Ejercicio 2 - Programa 1 Estrategia Fénix Corto Plazo

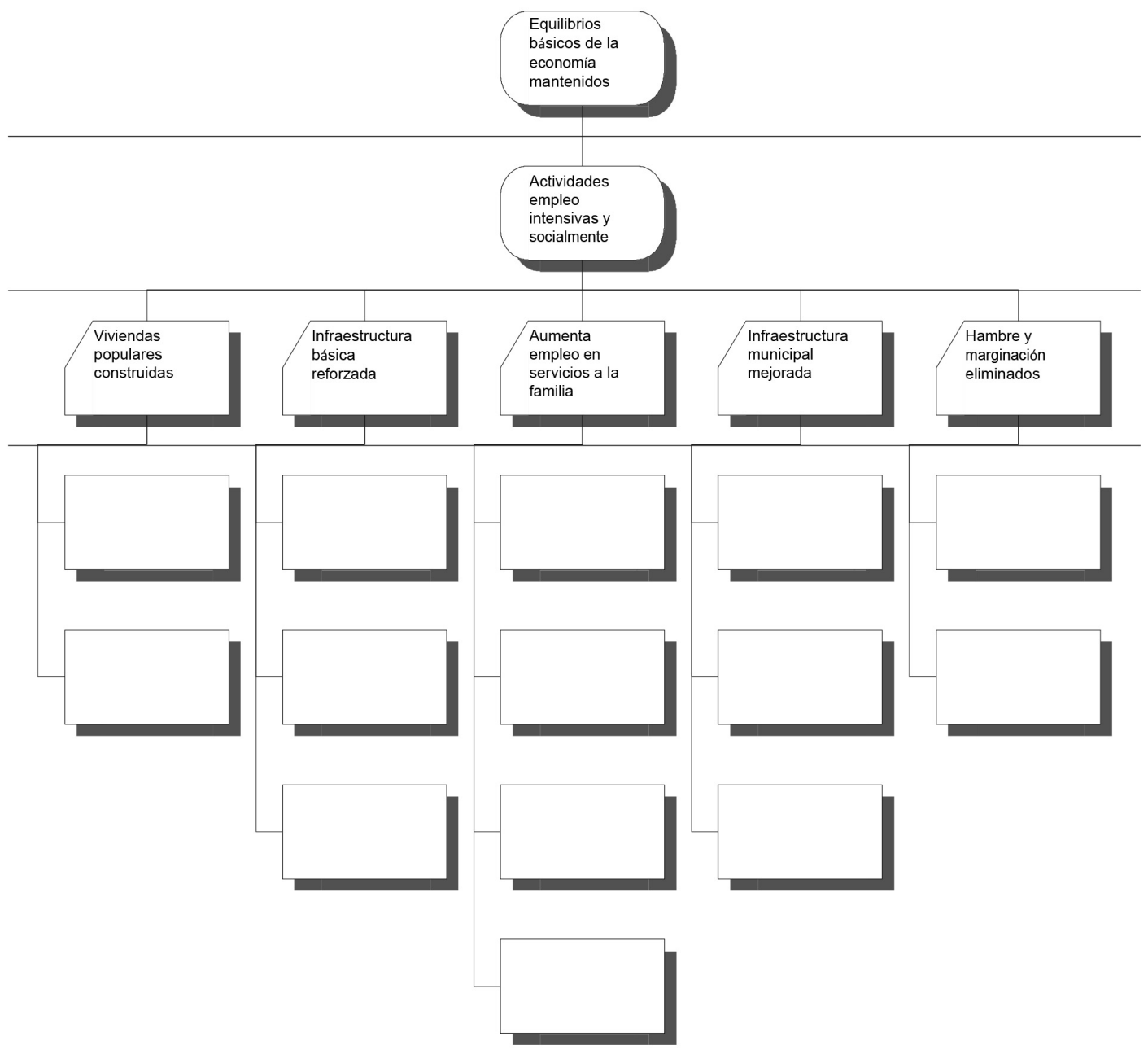


Una arquitectura del lenguaje aplicada a problemáticas institucionales de gestión pública.

El Plan Fénix y un discurso del presidente Kirchner

Gráfico 6. Jerarquía de Objetivos Ejercicio 2 - Programa 2 Estrategia Fénix Corto Plazo

\begin{tabular}{|c|c|c|c|}
\hline Resumen Narrativo & Indicadores & Medios de Verificación & Supuestos \\
\hline \multicolumn{4}{|l|}{ Propósito Estrategia } \\
\hline $\begin{array}{l}1 \text { Equilibrios básicos de la } \\
\text { economía mantenidos }\end{array}$ & $\begin{array}{l}\text { 1.1 Politica monetaria flexible y estable } \\
\text { 1.2 Politica financiera regulada } \\
\text { 1.3 Politica cambiaria regulada } \\
\text { 1.4 Circuito de empleo productivo restablecido (?) }\end{array}$ & $\begin{array}{l}1.1 .1 \\
1.2 .1 \\
1.3 .1 \\
1.4 .1\end{array}$ & 1 \\
\hline \multicolumn{4}{|l|}{ Propósito Programa } \\
\hline $\begin{array}{l}\text { Actividades empleo } \\
\text { intensivas y socialmente } \\
\text { deseables promovidas }\end{array}$ & 1.1 Reducción de conflictividad social (?) & 1.1 .1 & 1 \\
\hline \multicolumn{4}{|l|}{ Propósitos Proyectos } \\
\hline $\begin{array}{l}1 \text { Viviendas populares } \\
\text { construidas }\end{array}$ & 1.1 Se cubre el déficit primario de viviendas & 1.1 .1 & 1 \\
\hline $\begin{array}{l}2 \text { Infraestructura básica } \\
\text { reforzada }\end{array}$ & $\begin{array}{l}2.1 \text { Integración regional lograda } \\
2.2 \text { Integración Atlántico - Pacifico lograda }\end{array}$ & $\begin{array}{l}2.1 .1 \\
2.2 .1\end{array}$ & \\
\hline $\begin{array}{l}3 \text { Aumenta empleo en } \\
\text { servicios a la familia }\end{array}$ & $\begin{array}{l}\text { 3.1 Ampliación cuidado infantil } \\
\text { 3.2 Ampliación cuidado domiciliario ancianos } \\
\text { 3.3 Ampliación provisión salud en terreno }\end{array}$ & $\begin{array}{l}3.1 .1 \\
3.2 .1 \\
3.3 .1\end{array}$ & \\
\hline $\begin{array}{l}4 \text { Infraestructura municipal } \\
\text { mejorada }\end{array}$ & 4.1 & 4.1 .1 & \\
\hline $\begin{array}{l}5 \text { Hambre y marginación } \\
\text { eliminados }\end{array}$ & $\begin{array}{l}\text { 5.1 Seguro de empleo establecido } \\
5.2 \text { Asignación por hijo establecida } \\
5.3 \text { Formación de desocupados sistematizada }\end{array}$ & $\begin{array}{l}5.1 .1 \\
5.2 .1 \\
5.3 .1\end{array}$ & \\
\hline \multicolumn{4}{|l|}{ Componentes Proyectos } \\
\hline $\begin{array}{l}1.1 \\
2.1 \\
3.1 \\
4.1 \\
5.1\end{array}$ & 1 & $\begin{array}{l}1.1 .1 \\
2.1 .1 \\
3.1 .1 \\
4.1 .1 \\
5.1 .1\end{array}$ & 1 \\
\hline
\end{tabular}


Cuadro 6. Marco Lógico Ejercicio 2 - Programa 2 Estrategia Fénix Corto Plazo

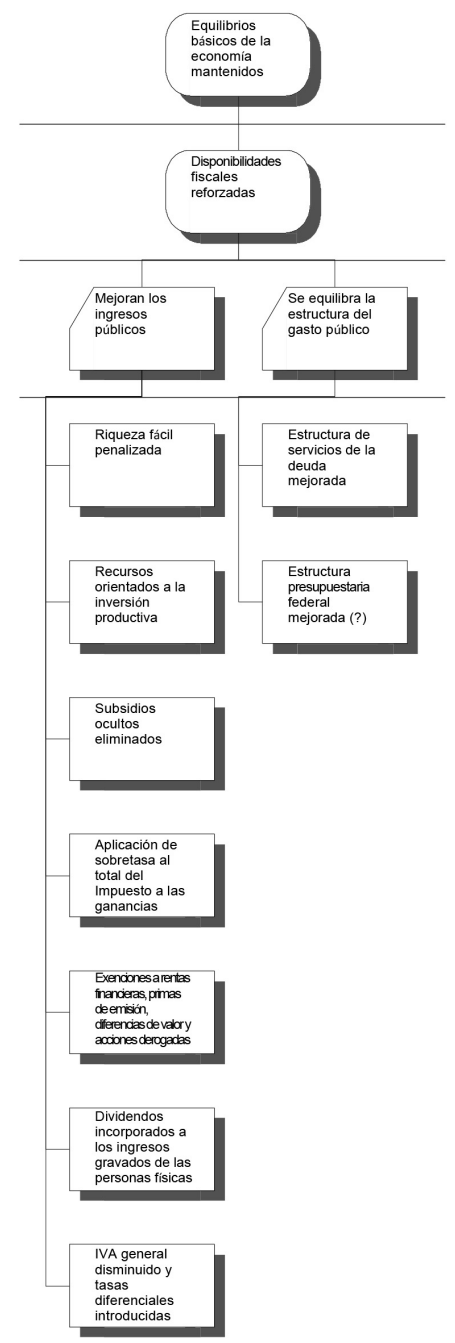


Una arquitectura del lenguaje aplicada a problemáticas institucionales de gestión pública.

El Plan Fénix y un discurso del presidente Kirchner

\section{Gráfico 7. Jerarquía de Objetivos Ejercicio 2 - Programa 3 Estrategia Fénix Corto Plazo}

\begin{tabular}{|c|c|c|c|c|}
\hline \multicolumn{2}{|c|}{ Resumen Narrativo } & Indicadores & Medios de Verificación & Supuestos \\
\hline \multicolumn{5}{|c|}{ Propósito Estrategia } \\
\hline 1 & $\begin{array}{l}\text { Equilibrios básicos de la } \\
\text { economía mantenidos }\end{array}$ & $\begin{array}{ll}\text { 1.1 } & \text { Política monetaria flexible y estable } \\
\text { 1.2 } & \text { Política financiera regulada } \\
\text { 1.3 } & \text { Política cambiaria regulada } \\
1.4 & \text { Circuito de empleo productivo restablecido (?) }\end{array}$ & $\begin{array}{l}1.1 .1 \\
1.2 .1 \\
1.3 .1 \\
1.4 .1 \\
\end{array}$ & 1 \\
\hline \multicolumn{5}{|c|}{ Propósito Programa } \\
\hline & $\begin{array}{l}\text { Disponibilidades fiscales } \\
\text { reforzadas }\end{array}$ & $\begin{array}{l}\text { 1.1 Estado con mayor capacidad de maniobra } \\
1.2 \text { Control público de las herramientas de } \\
\text { política económica }\end{array}$ & $\begin{array}{l}1.1 .1 \\
1.2 .1\end{array}$ & 1 \\
\hline \multicolumn{5}{|c|}{ Propósitos Proyectos } \\
\hline 1 & $\begin{array}{l}\text { Mejoran los ingresos } \\
\text { públicos }\end{array}$ & 1.1 & 1.1 .1 & 1 \\
\hline 2 & $\begin{array}{l}\text { Se equilibra la estructura } \\
\text { del gasto publico }\end{array}$ & 2.1 & 2.1 .1 & \\
\hline \multicolumn{5}{|c|}{ Componentes Proyectos } \\
\hline 1.1 & Riqueza fácil penalizada & 1 & 1.1.1 & 1 \\
\hline 1.2 & $\begin{array}{l}\text { Recursos orientados a la } \\
\text { inversión productiva }\end{array}$ & & 1.2 .1 & \\
\hline 1.3 & Subsidios ocultos eliminados & & 1.3 .1 & \\
\hline & $\begin{array}{l}\text { Aplicación de sobretasa al total } \\
\text { del Impuesto a las Ganancias }\end{array}$ & & 1.4 .1 & \\
\hline 1.5 & $\begin{array}{l}\text { Exenciones a rentas } \\
\text { financieras, primas de } \\
\text { emisión, diferencias de valor y } \\
\text { acciones y títulos valores, } \\
\text { derogadas }\end{array}$ & & 1.5 .1 & \\
\hline 1.6 & $\begin{array}{l}\text { Dividendos incorporados a los } \\
\text { ingresos gravados de las } \\
\text { personas fisicas }\end{array}$ & & 1.6 .1 & \\
\hline $1.7 \mathrm{I}$ & $\begin{array}{l}\text { IVA general disminuido y tasas } \\
\text { diferenciales introducidas }\end{array}$ & & 1.7 .1 & \\
\hline $\begin{array}{l}2.1 \\
2.2\end{array}$ & $\begin{array}{l}\text { Estructura de servicios de la } \\
\text { deuda mejorada } \\
\text { Estructura presupuestaria } \\
\text { federal mejorada (?) }\end{array}$ & $\begin{array}{l}\text { 2.1.1. Quita negociada } \\
2.1 .2 \text {. Tasas de interés rebajadas } \\
2.1 .3 \text {. Periodo de gracia ampliado }\end{array}$ & $\begin{array}{l}2.1 .1 \\
2.2 .1\end{array}$ & \\
\hline
\end{tabular}


Cuadro 7. Marco Lógico Ejercicio 2 - Programa 3 Estrategia Fénix Corto Plazo

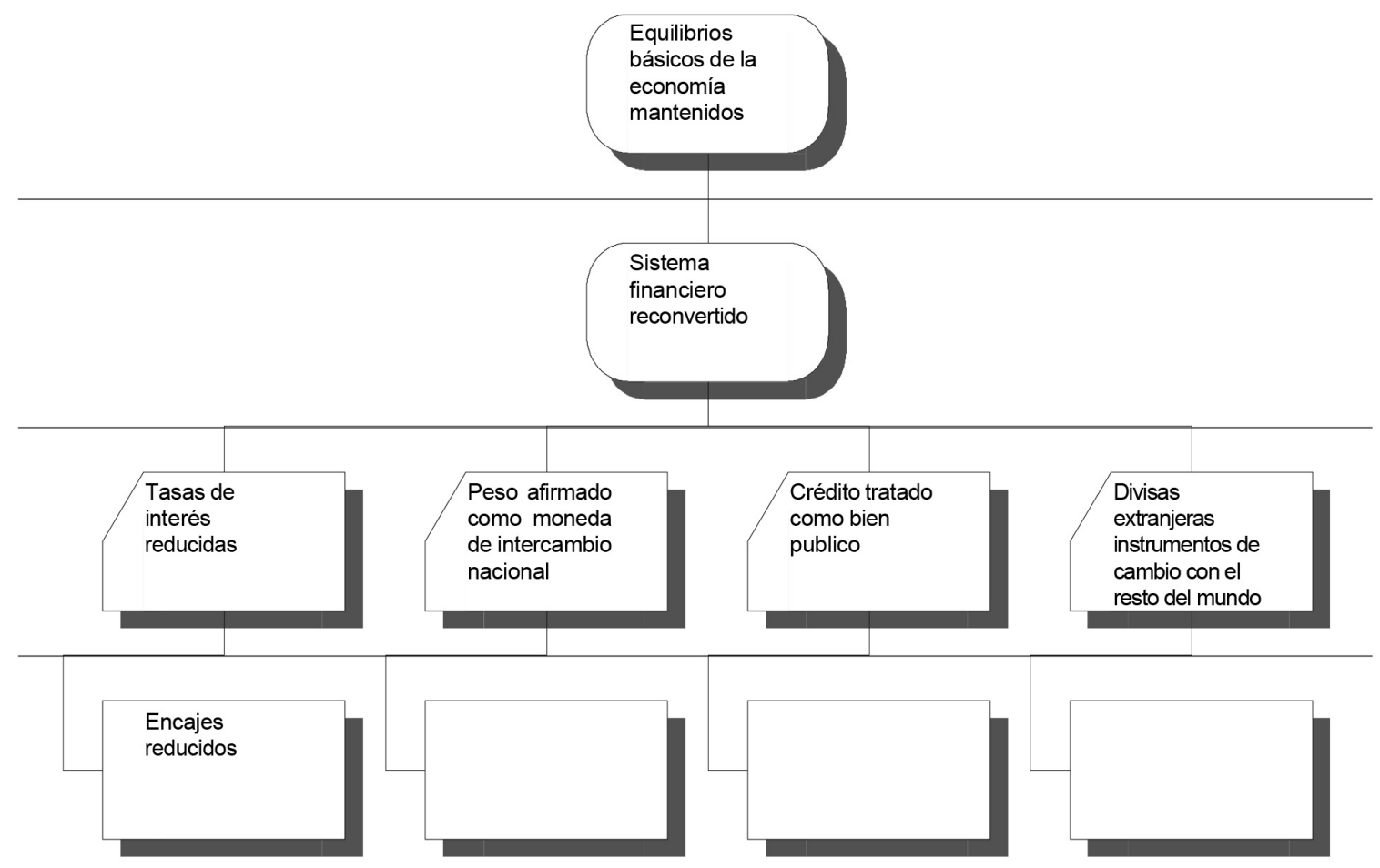


Una arquitectura del lenguaje aplicada a problemáticas institucionales de gestión pública.

El Plan Fénix y un discurso del presidente Kirchner

Gráfico 8. Jerarquía de Objetivos Ejercicio 2 - Programa 4 Estrategia Fénix Corto Plazo

\begin{tabular}{|c|c|c|c|}
\hline Resumen Narrativo & Indicadores & Medios de Verificación & Supuestos \\
\hline \multicolumn{4}{|l|}{ Propósito Estrategia } \\
\hline $\begin{array}{l}1 \text { Equilibrios básicos de la } \\
\text { economía mantenidos }\end{array}$ & $\begin{array}{ll}\text { 1.1 } & \text { Politica monetaria flexible y estable } \\
\text { 1.2 } & \text { Política financiera regulada } \\
\text { 1.3 } & \text { Política cambiaria regulada } \\
\text { 1.4 } & \text { Circuito de empleo productivo restablecido (?) }\end{array}$ & $\begin{array}{l}1.1 .1 \\
1.2 .1 \\
1.3 .1 \\
1.4 .1\end{array}$ & 1 \\
\hline \multicolumn{4}{|l|}{ Propósito Programa } \\
\hline $\begin{array}{l}\text { Sistema financiero } \\
\text { reconvertido }\end{array}$ & 1.1 & 1.1 .1 & 1 \\
\hline \multicolumn{4}{|l|}{ Propósitos Proyectos } \\
\hline 1 Tasas de interés reducidas & 1.1 & 1.1.1 & \multirow[t]{4}{*}{1} \\
\hline $\begin{array}{l}2 \text { Peso afirmado como } \\
\text { moneda de intercambio } \\
\text { nacional }\end{array}$ & 2.1 & 2.1 .1 & \\
\hline $\begin{array}{l}3 \text { Crédito tratado como bien } \\
\text { publico }\end{array}$ & 3.1 & 3.1 .1 & \\
\hline $\begin{array}{l}4 \text { Divisas extranjeras } \\
\text { instrumentos de cambio con } \\
\text { el resto del mundo } \\
\end{array}$ & 4.1 & 4.1 .1 & \\
\hline \multicolumn{4}{|l|}{ Componentes Proyectos } \\
\hline 1.1 Encajes reducidos & \multirow[t]{4}{*}{1} & 1.1 .1 & \multirow[t]{4}{*}{1} \\
\hline 2.1 & & 2.1 .1 & \\
\hline 3.1 & & 3.1 .1 & \\
\hline 4.1 & & 4.1 .1 & \\
\hline
\end{tabular}


Cuadro 8. Marco Lógico Ejercicio 2 - Programa 4 Estrategia Fénix Corto Plazo

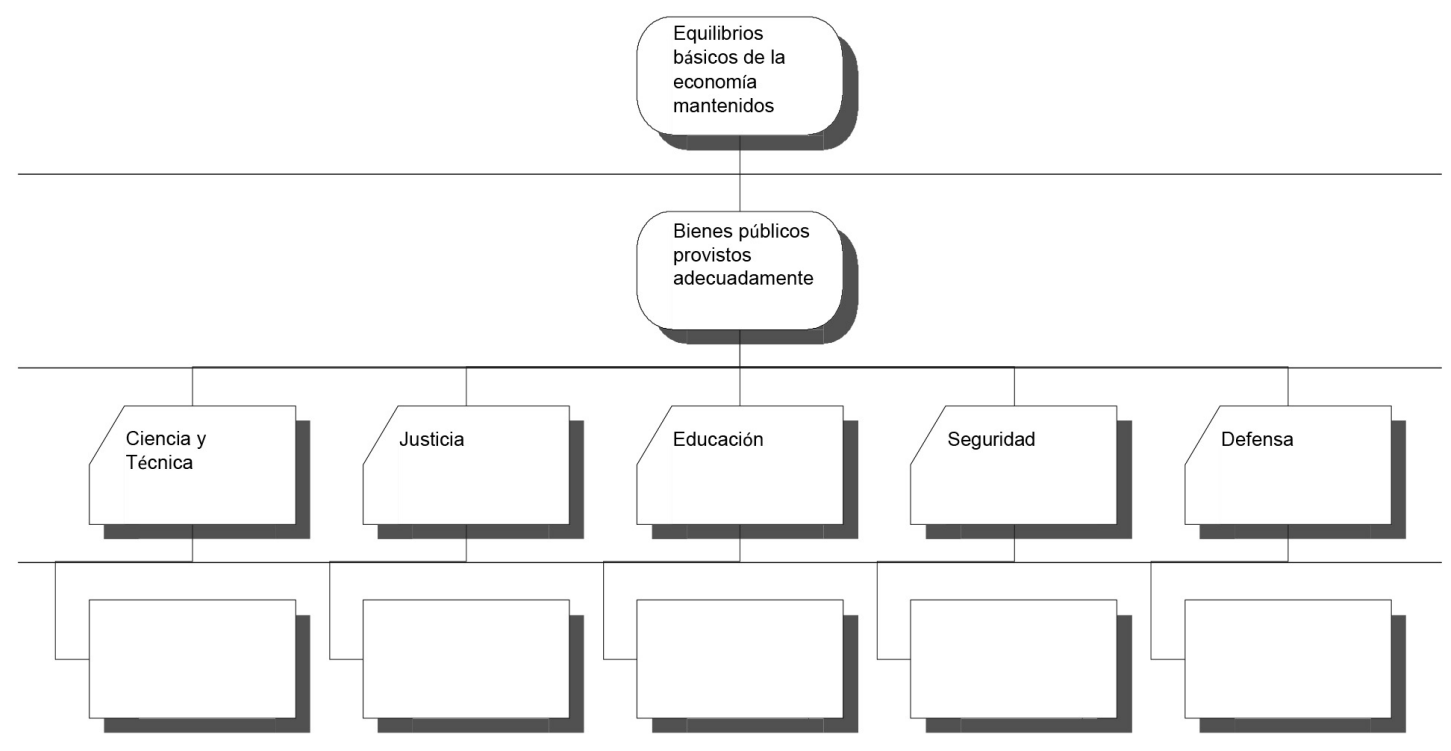

4.3.3. Ejercicio 3 
Una arquitectura del lenguaje aplicada a problemáticas institucionales de gestión pública.

El Plan Fénix y un discurso del presidente Kirchner

\subsubsection{Texto}

\begin{tabular}{|c|c|c|c|}
\hline Resumen Narrativo & Indicadores & Medios de Verificación & Supuestos \\
\hline \multicolumn{4}{|l|}{ Propósito Estrategia } \\
\hline $\begin{array}{l}\text { Equilibrios básicos de la } \\
\text { economía mantenidos }\end{array}$ & $\begin{array}{ll}1.1 & \begin{array}{l}\text { Politica monetaria flexible y } \\
\text { estable }\end{array} \\
1.2 & \text { Politica financiera regulada } \\
1.3 & \text { Politica cambiaria regulada } \\
1.4 & \begin{array}{l}\text { Circuito de empleo } \\
\text { productivo restablecido (?) }\end{array}\end{array}$ & $\begin{array}{l}1.1 .1 \\
1.2 .1 \\
1.3 .1 \\
1.4 .1\end{array}$ & 1 \\
\hline \multicolumn{4}{|l|}{ Propósito Programa } \\
\hline $\begin{array}{l}\text { Bienes públicos provistos } \\
\text { adecuadamente }\end{array}$ & 1.1 & 1.1 .1 & 1 \\
\hline \multicolumn{4}{|l|}{ Propósitos Proyectos } \\
\hline 1 Ciencia y Técnica & 1.1 & 1.1 .1 & \multirow[t]{5}{*}{1} \\
\hline 2 Justicia & 2.1 & 2.1 .1 & \\
\hline 3 Educación & 3.1 & 3.1 .1 & \\
\hline 4 Seguridad & 4.1 & 4.1 .1 & \\
\hline 5 Defensa & 5.1 & 5.1 .1 & \\
\hline \multicolumn{4}{|l|}{ Componentes Proyectos } \\
\hline $\begin{array}{l}1.1 \\
2.1 \\
3.1 \\
4.1 \\
5.1\end{array}$ & 1 & $\begin{array}{l}1.1 .1 \\
2.1 .1 \\
3.1 .1 \\
4.1 .1 \\
5.1 .1\end{array}$ & 1 \\
\hline
\end{tabular}

\section{“MEDIDAS DE MEDIANO Y LARGO PLAZO}

En el marco de las restricciones existentes, debe reconocerse que el desarrollo sigue siendo esencialmente un proceso interno de transformación e integración social, organización y movilización de los propios recursos.

La ejecución sistemática de los objetivos básicos buscados en los programas y proyectos sectoriales y especificos permitirá revertir la situación actual y generar el apoyo de la sociedad argentina al plan.

La decisión politica de ponerlo en marcha se constituirá, así, en el motor de un proceso virtuoso de desarrollo económico y recuperación humana que la nación espera y necesita.

\section{1) Deuda y financiamiento externo}

La viabilidad del programa de reactivación y desarrollo de la Argentina enfrenta 
gravísimos problemas de financiamiento externo e interno. Para hacer frente a estos problemas, y como contraparte de los esfuerzos para aumentar el ahorro interno - público y privado - se propone reprogramar por un plazo adecuado los pagos pasivos externos.

En lo referente a la deuda, es necesario cambiar el perfil temporal de vencimientos de intereses y amortizaciones para aliviar sustancialmente la carga de servicios en los próximos cinco años. Para ello hay que reestructurar la deuda pública a partir de una moratoria programada que determine por un periodo plurianual los recursos que asignará el presupuesto nacional para el servicio de la deuda.

Los pagos programados deben tomar en cuenta la disponibilidad de recursos necesarios para la puesta en marcha y ejecución del plan, en una escala ascendente que contemple la necesidad de un shock inicial de reactivación y el creciente superávit primario de las cuentas fiscales y saldos positivos del balance comercial que resultarán de su aplicación.

La reestructuración de la deuda requiere contemplar una reducción hacia un nivel razonable de las tasas de interés.

Se debe hacer un relevamiento de la deuda privada para su conformidad por el Banco Central de la República Argentina, la AFIP y la Aduana. Sobre esta base, se negociará con los deudores mayores una reprogramación de plazos y tasas de interés.

Es preciso acordar directamente con las grandes empresas, en especial las filiales de empresas extranjeras radicadas en la Argentina, la reinversión plena en el país de las utilidades por el plazo necesario para emerger de la crisis.

Para el período inicial, se propone negociar un paquete plurianual de créditos conforme con las posiciones del G-7 y de los organismos internacionales, orientado a facilitar el financiamiento de las importaciones necesarias para el programa de crecimiento económico.

\section{2) Economías regionales}

Se propone el lanzamiento de un programa nacional de apoyo y reconversión de las estructuras productivas del interior del país, con especial preferencia dirigido hacia el segmento de la pequeña producción rural y urbana.

En cada economía regional se propone organizar un consejo nacional de transformación productiva con equidad social con participación del estado nacional, los estados provinciales, las universidades, los organismos de ciencia y tecnología y los productores.

\section{3) Empleo, desempleo y marginación social}

Deben priorizarse aquellos que favorezcan a ciertos grupos, especialmente 
Una arquitectura del lenguaje aplicada a problemáticas institucionales de gestión pública.

El Plan Fénix y un discurso del presidente Kirchner

mecanismos de generación de empleo que conlleven una mejora de la calidad del empleo los trabajadores menos calificados.

Modificar la tendencia actual no sólo es funcional al objetivo de mejorar el bienestar de los trabajadores, sino también al de facilitar el crecimiento de la productividad.

Las políticas de carácter más activo, como los subsidios al empleo privado y los programas de generación directa en el sector público, así como los de entrenamiento y capacitación, también deben estar destinadas a mejorar la posibilidad de que los grupos más postergados obtengan empleo.

En este sentido, es preciso desarrollar estrategias de reescolarización en el sistema educativo formal de los desocupados con formación inferior al secundario completo, orientadas a la inserción ocupacional.

Es necesario instituir un amplio seguro de desocupación y medidas de apoyo directo que aseguren a la población acceso a la educación, la saludy, en general, a la satisfacción de sus necesidades básicas.

Se propone avanzar hacia la universalización de la seguridad social, estableciendo beneficios sociales derivados de la noción de derechos ciudadanos independientes del recorrido laboral de los individuos.

\section{4) Estructura y dinámica productiva argentina}

La nueva política debe abarcar toda la estructura productiva, orientada a forjar una estrategia de aliento general a la mayor producción y la productividad que abarque las interrelaciones entre la industria, el agro y las demás ramas de la economía.

La regulación no debe frenar el mercado, pero tampoco puede ni debe someterse a él. La prueba decisiva de la eficiencia de una estrategia como la que se propone reside en los resultados obtenidos en términos de desarrollo económico y equidad del sistema.

La política industrial debe estar dirigida a las empresas como agentes centrales dinámicos de la producción antes que a las ramas o sectores. Los aspectos sectoriales especificos serán tenidos en cuenta como telón de fondo de las decisiones al respecto.

Las medianas y pequeñas empresas deben recibir apoyos organizativos y técnicos que posibiliten su desarrollo y modernización, con condiciones de financiamiento apropiadas.

Es preciso que las políticas dirigidas a las grandes empresas estén inmersas en un proceso de negociación en el que las medidas de apoyo razonable demandadas 
por éstas tengan una clara contrapartida en términos de aportes efectivos a la dimensión y eficiencia de la producción local.

El paradigma de producir para exportar implica como condición previa y necesaria el producir de modo eficiente y en cantidades abundantes para el mercado nacional y regional.

\section{5) Globalización y desarrollo nacional. Política internacional}

Es preciso, para la recuperación de la economía argentina y la generación de empleo y bienestar, aplicar una política que remueva la dependencia externa mediante la mejora de los precios relativos de la producción argentina y su competitividad, el fomento de las exportaciones, la defensa del mercado interno (que en la mayoría de las economías exitosas constituye el principal destino de la producción de bienes y servicios) y el aumento del ahorro interno (que financia la mayor parte de la acumulación de capital).

Para ello se debe inducir a las filiales de empresas extranjeras que cierren su déficit operativo en divisas y se vinculen con la producción y el sistema de ciencia y tecnología locales, al tiempo que se impulsa una relación simétrica con el Brasil a partir de la división del trabajo intraindustrial.

Es necesario jugar un rol activo en el plano internacional, no dependiente de los intereses de las potencias centrales, sino teniendo en cuenta la verdadera problemática del escenario internacional y la naturaleza de las cuestiones en juego y de los países o actores afectados, y su relación con las necesidades del desarrollo argentino.

Es prioritario volver a instalar a la Argentina en su ámbito geográfico natural - América Latina - fortaleciendo y ampliando el MERCOSUR a través de políticas comunes en los planos económico, diplomático, social y tecnológico.

En este marco, es esencial el respeto del derecho internacional, especialmente de los derechos humanos, la libre autodeterminación de países y pueblos, la defensa de los valores culturales propios, del medio ambiente y la calidad de vida, y los procesos de paz que consoliden intereses históricos y culturales nacionales y regionales.

\section{6) Moneda y crédito}

El objetivo esencial es recuperar la moneda local y la posibilidad de ejercer politicas monetarias y crediticias autónomas y responsables que den sustento a la transformación social y productiva buscada.

Es necesario diseñar propuestas innovadoras que reduzcan la vulnerabilidad que presenta el sistema financiero y lo vuelquen hacia el financiamiento a la producción. 
Una arquitectura del lenguaje aplicada a problemáticas institucionales de gestión pública.

El Plan Fénix y un discurso del presidente Kirchner

Debe diseñarse una politica de encajes suficiente para la solidez del sistema, y que no conspire contra el financiamiento productivo $y$, al mismo tiempo, realizar acuerdos de préstamos contingentes con organismos financieros internacionales que fortalezcan las reservas del Banco Central para sustentar la moneda nacional, hasta tanto se diluya la restricción externa y se pueda acumular reservas derivadas de la cuenta corriente para este fin.

Se debe mantener la estabilidad del sistema financiero teniendo en cuenta la protección de los pequeños y medianos depositantes y tomadores de créditos, diferenciando las políticas que afecten a éstos respecto de las políticas orientadas a las grandes inversiones, particularmente las especulativas. Es necesario implementar una política estricta de creación de dinero que esté vinculada con la evolución de la economía real y que libere los fondos que ésta demanda para su funcionamiento.

Es preciso establecer controles sobre los flujos externos de capital que permitan reducir los efectos de las crisis financieras internacionales, con potencialidad para reducir los riesgos de iliquidez. Se aplicarán los controles que tengan un efecto positivo sobre el financiamiento de la inversión productiva, desalentando las operaciones especulativas y alentando selectivamente las inversiones externas directas.

\section{7) Política cambiaria y sus condiciones previas}

Debe recordarse que el valor del dinero es el valor de cambio del mismo respecto de los productos y servicios; es decir, su poder adquisitivo o poder de compra. De acuerdo con la ley orgánica del Banco Central, su obligación básica no consiste en mantener constante el tipo de cambio del peso en relación con cualquier otra moneda, sino su valor de cambio en relación con las mercancías. Por lo tanto el BCRA sólo debe preservar el tipo de cambio en la medida en que ello sea compatible con la finalidad fundamental de estabilizar el valor del dinero. Esto no ocurre cuando el tipo de cambio sólo puede mantenerse por medio de la baja interna de precios y salarios.

El abandono de un tipo de cambio de cambio fijo-cualquiera sea el camino que se elija-requiere, entre otras, de las siguientes condiciones previas y simultáneas: aumento del nivel de reservas hacia el promedio del año 2000; reordenamiento y saneamiento de las cuentas públicas; un sistema de seguro de desempleo que coloque a todos los hogares por encima de la línea de pobreza y un salario mínimo equivalente; renegociación de la deuda con quita y suspensión del pago de intereses; aumento de las protecciones efectivas relativas de las manufacturas más diferenciadas; imposición de retenciones a las exportaciones con fuertes ventajas comparativas presentes, tales como petróleo y energía; medidas para reducir la apertura 
financiera tales como imposición a las operaciones de moneda y fiscalización por el BCRA; compensación de efectos de la depreciación sobre los saldos de deudas y créditos de sectores de ingresos medio-bajos y pequeñas empresas.

En cuanto a los servicios públicos, desdolarización, reducción de tarifas, aplicación de la "neutralidad tributaria" contemplada en los contratos de privatización y plena vigencia de las normas generales de defensa de la competencia.

\section{8) Política comercial y externa. MERCOSUR y ALCA}

La Argentina debe tener una presencia muy alta y un fuerte perfil en las negociaciones multilaterales, más que en negociaciones con algunas áreas encaradas separadamente.

En relación con la OMC es preciso reclamar el cumplimiento estricto de los compromisos asumidos en la Ronda Uruguay y la adopción de disciplinas más estrictas en la aplicación de medidas antidumping.

En cuanto al MERCOSUR, es preciso preservar la unión aduanera y negociar conjuntamente, formular soluciones para los pocos sectores conflictivos y llevar a la práctica proyectos de integración conjunta en áreas de nueva competitividad.

Se debe concretar a la brevedad un acuerdo con la comunidad andina como paso para la constitución de un área de libre comercio para América del Sur.

Con referencia a las negociaciones del ALCA y el acuerdo UE-MERCOSUR, es preciso adoptar una posición firme por la cual sin acuerdo en el sector agropecuario y en el ALCA sobre medidas antidumping y eliminación de barreras no arancelarias, no se debe aceptar haber avance alguno.

Asimismo es necesario insistir en medidas de adaptación gradual y de apoyo financiero y técnico a sectores afectados por la liberalización.

\section{9) Política fiscal (reestructurada)}

Deben tomarse en cuenta aspectos presupuestarios y administrativos que contemplen implementar técnicas de presupuestos por programas, resultados y base cero; jerarquizar el organismo que elabora y coordina la confección y posterior control de gestión del Presupuesto de la Administración Pública Nacional; recuperar los organismos de Administración Fiscal virtualmente desmantelados; implementar un régimen unificado de control de las empresas privatizadas con participación de las universidades y de los usuarios; elaborar programas racionales y permanentes de lucha contra la evasión.

Asimismo debe diseñarse una reforma integral en materia tributaria, que comenzará a aplicarse en forma progresiva y que deberá elevar la carga o presión impositiva en jurisdicción nacional en un porcentaje significativo del PBI, con 
Una arquitectura del lenguaje aplicada a problemáticas institucionales de gestión pública.

El Plan Fénix y un discurso del presidente Kirchner

particular énfasis en los impuestos a las Ganancias y sobre Ganancias de Capital, especialmente en los sectores de altos y muy altos ingresos.

Debe dictarse una nueva ley de Coparticipación Federal que contemple una acción conjunta y coordinada de la Nación, las Provincias y la Capital Federal en su administración y lucha contra la evasión.

En lo referente a aspectos previsionales, es necesario efectuar una revisión integral del régimen actual, tendiendo al control para erradicar el trabajo "no declarado" y la evasión en materia de aportes, así como la reinstalación de los aportes patronales, inicialmente en los sectores no transables de la economía.

\section{0) Producción tecnológica y competitividad internacional}

Debe acordarse una nueva agenda en materia de políticas de fomento productivo y tecnológico encaminada a revitalizar la productividad y competitividad del aparato productivo argentino.

En lo referente a tecnología, se debe desarrollar e inducir la utilización de tecnologías con mayor valor agregado doméstico e ingeniería local; agregar valor y manejo ecológicamente sustentable a los recursos naturales; inducir la difusión de tecnologías de la información; desarrollar los sectores productores de software $y$ de una industria local de contenidos; articular el sistema nacional, regional y sectorial de innovación; desarrollar capital humano y favorecer el reciclaje de la fuerza laboral; implementar políticas de creación de nuevas ventajas comparativas en industrias asociadas con el uso de nuevas tecnologías.

En materia de competitividad internacional, es preciso mejorar competitividad e inserción internacional en industrias procesadoras de recursos naturales; desarrollar sectores de servicios a la producción asociados con la explotación de recursos naturales; brindar protección a industrias nacientes con contenido tecnológico local; reducir el impacto de las barreras para arancelarias a los productos locales.

En cuanto a los regímenes tecnológicos y competitivos sectoriales, se requiere profundizar el papel de la competencia y los marcos regulatorios como instrumentos de defensa del consumidor y como fuente de fondos para financiar el establecimiento de nuevas inversiones productivas.

\section{1) Reformas institucionales y politicas (11a). El rol del Estado (11b)}

Es necesario tener claro que, a pesar de su creciente descrédito y del virtual desmantelamiento a que lo ha sometido la embestida neoconservadora, el Estado sigue siendo la máxima instancia de articulación social.

Es necesario lograr un mejor Estado, tecnológica y culturalmente más avanza- 
do, que contemple el fortalecimiento de aquellas instituciones y programas que promuevan nuevos equilibrios en los planos de la redistribución del ingreso y el poder social y que priorice los necesarios cambios en las instancias subnacionales, incluyendo mecanismos de participación ciudadana en los distintos niveles, en el marco de un replanteo del rol y la agenda del Estado, así como de sus relaciones con la sociedad civil.

Las reformas hacia adentro del Estado deben implantar nuevas tecnologías de gestión y transformar las pautas culturales vigentes, para lo cual requieren la firme voluntad política de quienes lo conducen.

En lo relativo a la promoción del desarrollo, el papel preponderante cumplido por el Estado como productor de bienes y servicios, como responsable principal del avance científico y tecnológico, como regulador del mercado laboral, como constructor de la infraestructura material del país o como interventor en el comercio externo ha dado paso a un creciente abandono de estas funciones -lo que ha tendido a favorecer al gran capital privado, nacional y transnacional-; en tal sentido, el estado nacional debe redefinir este rol, con las modalidades que resulten más conducentes para los objetivos acordados.

En cuanto a las funciones relativas al bienestar de la población-salud, educación, previsión social, vivienda - urge que el Estado reasuma su responsabilidad en estos aspectos indelegables, fortaleciendo sus principales instituciones y con el claro convencimiento de que un Estado débil es incapaz de asumir el irrenunciable papel que le corresponde como articulador social y orientador de la dinámica y dirección global de la sociedad, estableciendo nuevos equilibrios en las relaciones de dominación social y política.

12) Regulación de los servicios públicos y concentración económica

Se debe promover, y aun forzar, patrones de comportamiento empresario que se asemejen, en todo lo posible, a los esperables en mercados eficientes, como un ineludible mecanismo en materia de regulación de monopolios naturales, sancionando y aplicando normas antimonopólicas especificas.

Es necesario diseñar y aplicar políticas orientadas a regular el comportamiento y rentabilidad de los servicios públicos privatizados. Para ello se requiere la revisión de los siguientes temas: precios de base de estos servicios para limitar las ganancias extraordinarias; eliminación de las demoras regulatorias y aplicación efectiva de los factores de eficiencia; anulación de las cláusulas de ajustes periódicos de las tarifas mediante indexaciones que contravienen la ley de convertibilidad; reglamentación de la ley de defensa de la competencia en los que concierne a los 
Una arquitectura del lenguaje aplicada a problemáticas institucionales de gestión pública.

El Plan Fénix y un discurso del presidente Kirchner

servicios públicos privatizados.

Por otra parte, es necesario que los bienes y servicios de producción nacional tengan preferencia en las compras de las empresas privatizadas.

13) Politica y vida social frente a las propuestas de cambio en la economía

La transformación fundacional requerida para ponernos de pie requiere la conformación de una nueva coalición social que refleje al mismo tiempo la voluntad de superación de la crisis y la formalización de una nueva identidad que debemos construir entre todos.

Esta coalición debe integrar aquellos sectores que encarnan la producción, provenientes del trabajo y del capital, y a las actividades esenciales que hacen que nuestra sociedad continúe funcionando.

La unión para la reparación de la Nación requiere atravesar y enlazar a los partidos politicos y las organizaciones de la sociedad civil de forma de alcanzar un amplio consenso de bases mínimas respetadas por todos, que exprese, de manera inequívoca, un programa de revitalización del que nadie que desee participar legitimamente pueda sentirse excluido.

El consenso social determinará el grado de intervención del Estado y del mercado en la asignación de los recursos y la distribución de la riqueza. Este criterio se ha demostrado perfectamente compatible con el funcionamiento del sistema capitalista en las naciones más desarrolladas del planeta. También deberá descansar sobre este consenso la reconstrucción del concepto de ciudadanía fiscal, por el que todos nos convertimos en obligatorios sostenedores del estado, en relación con una equitativa distribución de las cargas impositivas. Nos espera una ardua tarea orientada a la ocupación positiva de nuestro territorio y a la integración con nuestros vecinos del Mercosur a partir de la fijación de razonables intereses nacionales y regionales. Debemos ampliar y consolidar los avances del agro y erigir las bases de la nueva industria argentina, la del valor agregado del conocimiento y la inserción en los mercados internacionales y restablecer al estado en el rol de árbitro y protector, y no de amenaza para los argentinos.

Debemos fortalecer la democracia en el marco del imperio de estado de derecho establecido por nuestra Constitución, procurando el pleno y transparente funcionamiento de los partidos políticos.

Se impone retomar los resortes del poder nacional para las determinaciones estratégicas que hacen a los grandes temas del país.

Cuanto antes comencemos, menor será el sufrimiento causado por la herencia 
recibida y más rápida la unión de la ciudadanía alrededor de un nuevo consenso social. El parto de una nueva sociedad hará a la Argentina renacer para recobrar lo que sobraba a nuestros antecesores: coraje y confianza en el futuro".

Buenos Aires, septiembre de 2001.

4.3.3.2. Análisis

En este tercer ejercicio son válidos los comentarios ya efectuados en los dos anteriores y en la sección 2.

El árbol de jerarquía de objetivos y el marco lógico de la estrategia que emerge del texto 3 se presentan en las páginas que siguen.

Solo me cabe enfatizar lo que sugiriera como paso necesario al final del ejercicio 1 . La necesidad de definir relaciones causales entre categorías de "objetivos", lo cual no es función de un ejercicio textual analítico ex-post, como el que he efectuado aquí. Encontrar tales relaciones causales y a la vez encontrar las causas de los objetivos formulados, y quizás su mejor formulación, solo resultará de un proceso dialógico entre los productores del "Plan Fénix", cuyo objetivo sería efectuar un análisis de involucrados y formular un árbol de jerarquías de problemas. Esta es quizás la tarea principal que habría que realizar para lograr una definición más afín a un plan estratégico/político.

Gráfico 9. Estructura de Objetivos Ejercicio 3 - Fénix Largo Plazo Cuadro 9. Marco Lógico Ejercicio 3 - Fénix Largo Plazo (3 partes) 
Una arquitectura del lenguaje aplicada a problemáticas institucionales de gestión pública.

El Plan Fénix y un discurso del presidente Kirchner

5. UN CASO DEDUCTIVO: TRANSFORMACIÓN DE UN DISCURSO EN UNA

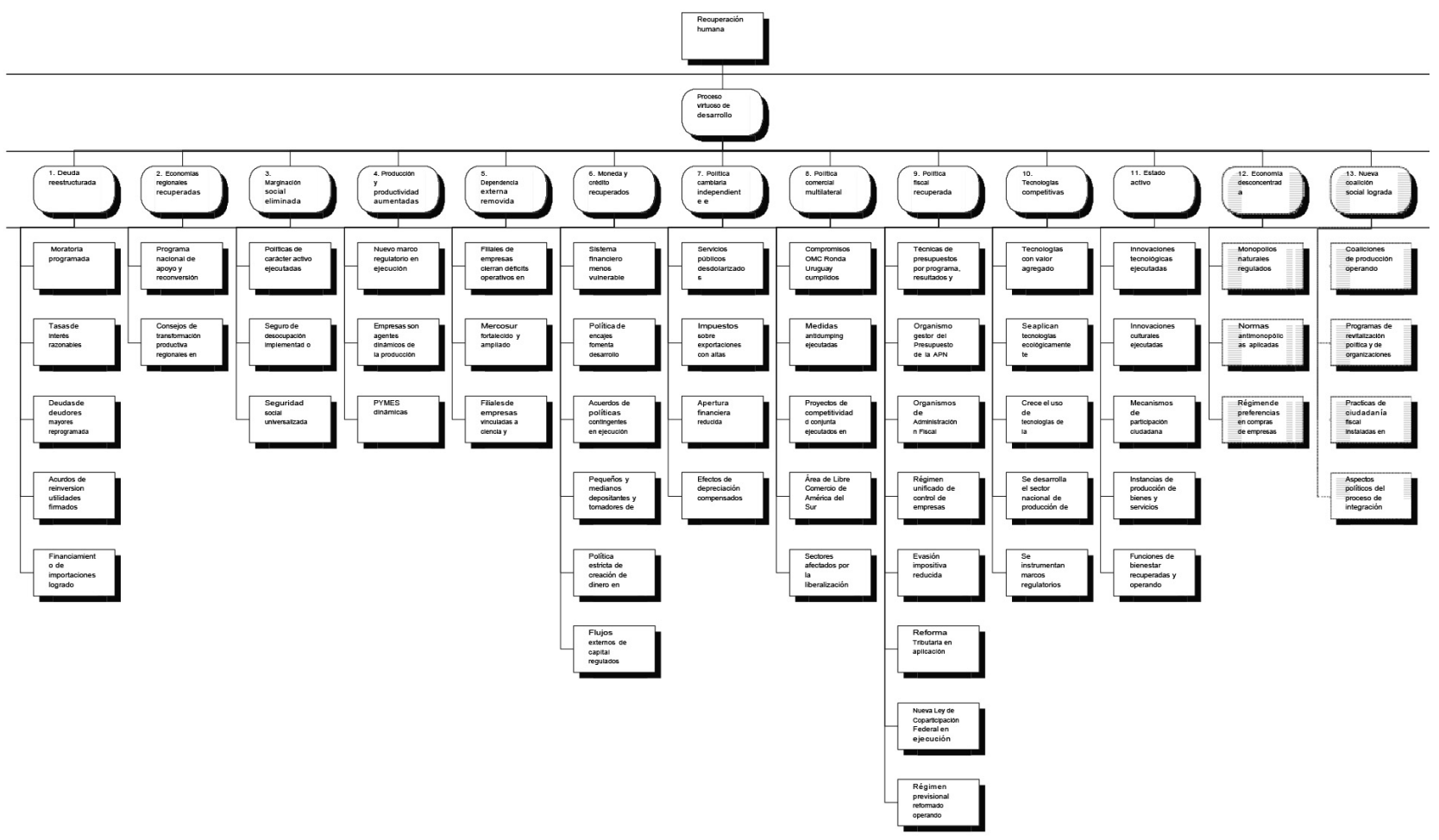




\section{ESTRATEGIA}

\begin{tabular}{|c|c|c|c|}
\hline Resumen Narrativo & Indicadores & Medios de Verificación & Supuestos \\
\hline \multicolumn{4}{|l|}{ Fin Estrategia } \\
\hline 1 Recuperación humana & 1.1 & 1.1.1 & 1 \\
\hline \multicolumn{4}{|l|}{ Propósito Estrategia } \\
\hline Proceso virtuoso de desarrollo & 1.1 & 1.1.1 & 1 \\
\hline \multicolumn{4}{|l|}{ Propósitos Programas } \\
\hline $\begin{array}{ll}1 & \text { Deuda reestructurada } \\
2 & \\
\end{array}$ & $\begin{array}{l}\text { 1.1 Perfil temporal de vencimientos de } \\
\text { intereses y amortizaciones mejorado, en } \\
\text { los próximos } 5 \text { años }\end{array}$ & 1.1 .1 & 1 \\
\hline $\begin{array}{|ll|}3 & \begin{array}{l}\text { Economías regionales } \\
\text { recuperadas }\end{array} \\
\end{array}$ & $\begin{array}{l}2.1 \\
3.1 \\
\end{array}$ & $\begin{array}{l}2.1 .1 \\
3.1 .1\end{array}$ & \\
\hline 4 Marginación social eliminada & 4.1 & 4.1 .1 & \\
\hline $\begin{array}{|ll|}5 & \begin{array}{l}\text { Producción y productividad } \\
\text { aumentadas }\end{array} \\
\end{array}$ & $\begin{array}{l}\text { 5.1 Mejoran los precios relativos } \\
\text { 5.2 Mejora la competitividad }\end{array}$ & $\begin{array}{l}5.1 .1 \\
5.2 .1\end{array}$ & \\
\hline $6 \begin{array}{l}\text { Dependencia externa } \\
\text { removida }\end{array}$ & $\begin{array}{l}\text { 6.1 Políticas monetarias y crediticias } \\
\text { autónomas } \\
\text { 6.2 Sistema financiero estable }\end{array}$ & $\begin{array}{l}6.1 .1 \\
6.2 .1 \\
\end{array}$ & \\
\hline \begin{tabular}{|l}
$77 \begin{array}{l}\text { Moneda y crédito } \\
\text { recuperados }\end{array}$ \\
\end{tabular} & $\begin{array}{l}7.1 \text { Valor de cambio mantenido en } \\
\text { relación con las mercancías } \\
\begin{array}{l}7.2 \text { Precios y salarios no sometidos a la baja } \\
\text { interna }\end{array} \\
\end{array}$ & $\begin{array}{l}7.1 .1 \\
7.2 .1\end{array}$ & \\
\hline $\begin{array}{|ll|}8 & \begin{array}{l}\text { Política cambiaria } \\
\text { independiente }\end{array} \\
\end{array}$ & 8.1 & 8.1 .1 & \\
\hline 9 Política comercial multilateral & 9.1 & 9.1 .1 & \\
\hline 10 Política fiscal recuperada & $\begin{array}{l}\text { 10.1 Aumenta productividad } \\
10.2 \text { Aumenta competitividad }\end{array}$ & $\begin{array}{l}10.1 .1 \\
10.2 .1 \\
\end{array}$ & \\
\hline 11 Tecnologías competitivas & 11.1 & 11.1.1 & \\
\hline 12 Estado activo & 12.1 & 12.1.1 & \\
\hline 13 Economía desconcentrada & 13.1 & 13.1.1 & \\
\hline \multicolumn{4}{|l|}{$\begin{array}{l}14 \text { Nueva coalición social } \\
\text { lograda }\end{array}$} \\
\hline \multicolumn{4}{|l|}{ Propósitos Proyectos } \\
\hline 1.1 Moratoria programada & 1.1 .1 & 1.1.1.1 & \multirow[t]{5}{*}{1} \\
\hline 1.2Tasas de interés razonables & 1.2 .1 & 1.2.1.1 & \\
\hline $\begin{array}{l}\text { 1.3 Deudas de deudores } \\
\text { mayores reprogramadas }\end{array}$ & 1.3 .1 & 1.3.1.1 & \\
\hline $\begin{array}{c}\text { 1.4 Acuerdos de reinversión } \\
\text { utilidades firmados }\end{array}$ & 1.4 .1 & 1.4.1.1 & \\
\hline \begin{tabular}{|l|}
$\begin{array}{l}\text { 1.5 Financiamiento de } \\
\text { importaciones firmados }\end{array}$ \\
\end{tabular} & 1.5 .1 & 1.5.1.1 & \\
\hline
\end{tabular}


Una arquitectura del lenguaje aplicada a problemáticas institucionales de gestión pública.

El Plan Fénix y un discurso del presidente Kirchner

\begin{tabular}{|c|c|c|c|}
\hline Resumen Narrativo & Indicadores & Medios de Verificación & Supuestos \\
\hline $\begin{array}{l}\text { 2.1 Programa nacional de apoyo y } \\
\text { reconversión en ejecución }\end{array}$ & 2.1 .1 & 2.1.1.1 & \\
\hline \begin{tabular}{|l|}
2.2 Consejos de transformación \\
productiva regionales en operación
\end{tabular} & 2.2 .1 & 2.2 .1 .1 & \\
\hline $\begin{array}{l}\text { 3.1 Políticas de carácter activo } \\
\text { ejecutadas }\end{array}$ & $\begin{array}{l}\text { 3.1.1 Grupos más postergados también } \\
\text { obtienen empleo }\end{array}$ & 3.1 .1 .1 & \\
\hline $\begin{array}{l}3.2 \text { Seguro de desocupación } \\
\text { implementado }\end{array}$ & $\begin{array}{l}\text { 3.2.1 Población accede a salud, } \\
\text { educación y necesidades básicas }\end{array}$ & 3.2 .1 .1 & \\
\hline 3.3 Seguridad social universalizada & 3.3 .1 & 3.3 .1 .1 & \\
\hline 4.1 Nuevo marco regulatorio en ejecución & $\begin{array}{l}\text { 4.1.1 Mercados responden generando } \\
\text { desarrollo económico con equidad }\end{array}$ & 4.1 .1 .1 & \\
\hline $\begin{array}{l}4.2 \text { Empresas son agentes dinámicos de } \\
\text { la producción }\end{array}$ & 4.2 .1 & 4.2 .1 .1 & \\
\hline 4.3 PYMES dinámicas & 4.3 .1 & 4.3 .1 .1 & \\
\hline $\begin{array}{l}5.1 \text { Filiales de empresas cierran déficits } \\
\text { operativos en divisas }\end{array}$ & 5.1 .1 & 5.1 .1 .1 & \\
\hline 5.2 Mercosur fortalecido y ampliado & 5.2.1 Relación simétrica con Brasil & 5.2 .1 .1 & \\
\hline $\begin{array}{l}\text { 5.3 Filiales de empresas vinculadas con } \\
\text { ciencia y tecnología nacionales }\end{array}$ & 5.3 .1 & 5.3 .1 .1 & \\
\hline 6.1 Sistema financiero menos vulnerable & 6.1.1 Crédito volcado a la producción & 6.1 .1 .1 & \\
\hline 6.2 & 6.2 .1 & 6.2 .1 .1 & \\
\hline $\begin{array}{l}\text { 6.3 Política de encajes fomenta } \\
\text { desarrollo productivo }\end{array}$ & 6.3.1 & 6.3.1.1 & \\
\hline $\begin{array}{l}6.4 \text { Acuerdos de políticas contingentes en } \\
\text { ejecución }\end{array}$ & 6.4 .1 & 6.4.1.1 & \\
\hline $\begin{array}{c}6.5 \text { Pequeños y medianos depositantes y } \\
\text { tomadores de crédito protegidos }\end{array}$ & 6.5 .1 & 6.5 .1 .1 & \\
\hline $\begin{array}{l}6.6 \text { Política estricta de creación de } \\
\text { dinero en ejecución }\end{array}$ & $\begin{array}{l}\text { 6.6.1 Operaciones especulativas } \\
\text { reducidas }\end{array}$ & 6.6 .1 .1 & \\
\hline \begin{tabular}{|l|}
6.7 Flujos externos de capital regulados \\
7.1 Servicios públicos desdolarizados \\
\end{tabular} & $\begin{array}{l}7.1 .1 \\
7.2 .1 \\
\end{array}$ & $\begin{array}{l}7.1 .1 .1 \\
7.2 .1 .1 \\
\end{array}$ & \\
\hline \multicolumn{4}{|l|}{\begin{tabular}{|l}
7.2 Impuestos sobre exportaciones \\
con altas ventajas comparativas \\
en ejecución
\end{tabular}} \\
\hline 7.3 Apertura financiera reducida & 7.3 .1 & 7.3 .1 .1 & \\
\hline $\begin{array}{c}7.4 \text { Efectos de depreciación } \\
\text { compensados }\end{array}$ & 7.4 .1 & 7.4 .1 .1 & \\
\hline $\begin{array}{l}\text { 8.1 Compromisos OMC Ronda } \\
\text { Uruguay cumplidos }\end{array}$ & 8.1 .1 & 8.1.1.1 & \\
\hline 8.2 Medidas antidumping ejecutadas & 8.2 .1 & 8.2 .1 .1 & \\
\hline $\begin{array}{l}\text { 8.3 Proyectos de competitividad } \\
\text { conjunta ejecutados en } \\
\text { MERCOSUR }\end{array}$ & 8.3 .1 & 8.3 .1 .1 & \\
\hline \begin{tabular}{|l|} 
8.4 Área de Libre Comercio de \\
América del Sur concretada
\end{tabular} & 8.4 .1 & 8.4 .1 .1 & \\
\hline $\begin{array}{l}\text { 8.5 Sectores afectados por la } \\
\text { liberalización apoyados }\end{array}$ & 8.5 .1 & 8.5 .1 .1 & \\
\hline
\end{tabular}

Cuaderno Urbano. Espacio, Cultura, Sociedad - Vol. 15 - N. 15 (Noviembre de 2013)- Pp. 137-191 - ISNN1666-6186 


\begin{tabular}{|c|c|c|c|}
\hline Resumen Narrativo & Indicadores & Medios de Verificación & Supuestos \\
\hline 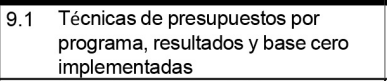 & 9.1 .1 & 9.1 .1 .1 & \multirow[t]{26}{*}{$\begin{array}{l}\text { Omitido la última } \\
\text { página del Marco } \\
\text { Lógico. }\end{array}$} \\
\hline \begin{tabular}{|l}
$9.2 \begin{array}{l}\text { Organismo gestor del Presupuesto } \\
\text { de la APN jerarquizado }\end{array}$ \\
\end{tabular} & 9.2 .1 & 9.2 .1 .1 & \\
\hline $\begin{array}{ll}9.3 & \begin{array}{l}\text { Organismos de Administración Fiscal } \\
\text { recuperados }\end{array}\end{array}$ & 9.3 .1 & 9.3 .1 .1 & \\
\hline $\begin{array}{|ll|}9.4 & \begin{array}{l}\text { Régimen unificado de control de } \\
\text { empresas privatizadas en operación }\end{array} \\
\end{array}$ & 9.4 .1 & 9.4 .1 .1 & \\
\hline $\begin{array}{|ll|}9.5 & \text { Evasión impositiva reducida } \\
\end{array}$ & 9.5 .1 & 9.5 .1 .1 & \\
\hline 9.6 $\quad$ Reforma Tributaria en aplicación & 9.6 .1 & 9.6 .1 .1 & \\
\hline \begin{tabular}{|ll}
9.7 & Nueva Ley de Coparticipación \\
& Federal en ejecución \\
\end{tabular} & 9.7 .1 & 9.7 .1 .1 & \\
\hline \begin{tabular}{|ll}
9.8 & $\begin{array}{l}\text { Régimen previsional reformado } \\
\text { operando }\end{array}$ \\
\end{tabular} & 9.8 .1 & 9.8 .1 .1 & \\
\hline $\begin{array}{l}\text { 10.1 Tecnologías con valor agregado } \\
\text { domestico utilizadas }\end{array}$ & 10.1 .1 & 10.1.1.1 & \\
\hline $\begin{array}{l}10.2 \text { Se aplican tecnologías } \\
\text { ecológicamente sustentables }\end{array}$ & 10.2 .1 & 10.2 .1 .1 & \\
\hline $\begin{array}{l}\text { 10.3 Crece el uso de tecnologías de la } \\
\text { información }\end{array}$ & 10.3 .1 & 10.3 .1 .1 & \\
\hline $\begin{array}{l}10.4 \text { Se desarrolla el sector nacional de } \\
\text { producción de software y } \\
\text { contenidos }\end{array}$ & 10.4 .1 & 10.4 .1 .1 & \\
\hline $\begin{array}{r}10.5 \text { Se instrumentan marcos } \\
\text { regulatorios apropiados }\end{array}$ & 10.5 .1 & 10.5 .1 .1 & \\
\hline $\begin{array}{c}11.1 \text { Innovaciones tecnológicas } \\
\text { ejecutadas }\end{array}$ & 11.1 .1 & 11.1.1.1 & \\
\hline 11.2 Innovaciones culturales ejecutadas & 11.2 .1 & 11.2.1.1 & \\
\hline $\begin{array}{l}11.3 \text { Mecanismos de } \\
\text { participación ciudadana } \\
\text { instalados }\end{array}$ & 11.3 .1 & 11.3.1.1 & \\
\hline $\begin{array}{l}11.4 \text { Instancias de producción de bienes } \\
\text { y servicios operando }\end{array}$ & 11.4 .1 & 11.4 .1 .1 & \\
\hline $\begin{array}{l}11.5 \text { Funciones de bienestar recuperadas } \\
\text { y operando equitativamente }\end{array}$ & 11.5 .1 & 11.5 .1 .1 & \\
\hline 12.1 Monopolios naturales regulados & 12.1 .1 & 12.1.1.1 & \\
\hline 12.2 Normas antimonopólicas aplicadas & 12.2 .1 & 12.2.1.1 & \\
\hline $\begin{array}{l}\begin{array}{l}\text { 12.3 Régimen de preferencias en } \\
\text { compras de empresas privatizadas } \\
\text { operando }\end{array} \\
\end{array}$ & 12.3 .1 & 12.3 .1 .1 & \\
\hline 13.1 Coaliciones de producción operando & 13.1.1 & 13.1.1.1 & \\
\hline \begin{tabular}{|l|}
$\begin{array}{l}\text { 13.2 Programas de revitalización política y } \\
\text { de organizaciones de la sociedad } \\
\text { civil }\end{array}$ \\
\end{tabular} & 13.2 .1 & 13.2 .1 .1 & \\
\hline \multicolumn{3}{|l|}{ operando } & \\
\hline $\begin{array}{l}\text { 13.3 Practicas de ciudadanía } \\
\text { fiscal instaladas en la } \\
\text { sociedad }\end{array}$ & 13.3 .1 & 13.3 .1 .1 & \\
\hline $\begin{array}{l}\text { 13.4 Aspectos políticos del proceso de } \\
\text { integración territorial política y } \\
\text { socioeconómica operando }\end{array}$ & 13.4 .1 & 13.4 .1 .1 & \\
\hline
\end{tabular}


Una arquitectura del lenguaje aplicada a problemáticas institucionales de gestión pública.

El Plan Fénix y un discurso del presidente Kirchner

Este caso representa la inversa lógica del caso precedente, ya que consiste en partir de un objetivo e imaginar las condiciones necesarias para su logro. El objetivo es una frase del presidente Néstor Kirchner que formó parte de su discurso en ocasión de su visita a Washington después de asumir la Presidencia de la Nación. El señor presidente, entre otras cosas que nos dijo a los argentinos reunidos para saludarlo, mencionó un deseo cuyo fraseo aparentemente trivial y cuya sencillez y simultánea enormidad nos dejó pensando a todos. El deseo que expresó el presidente fue: "QUIERO QUE LA ARGENTINA SEA UN PAÍS NORMAL".

Meditando sobre su sencillez panglosiana y su enormidad krausiana cavilé sobre cómo sería, ingenuamente, posible un "país normal", sujeto a la demanda ética implícita en el discurso kraussiano. Inmediatamente surgió la intuición de que tal combinación en el mundo real requeriría una revolución de nuestros comportamientos, y que ella debía fundamentalmente pasar por el reemplazo de nuestras nacionalizadas y abusadas frases referidas siempre a alguna forma de la "vergüenza ajena" por una nueva práctica personal y cotidiana basada sobre el concepto de la "vergüenza propia".

Decidí imaginar entonces cómo serían los resúmenes narrativos, los indicadores, los medios de verificación y los supuestos, que nos podrían llevar, juntamente con los actores principales de la escena nacional, por un viaje hacia el "lado claro del corazón", hacia un "país normal". He narrado estas imaginaciones panglosianas en un intentado lenguaje krausiano, ubicándolas en una escalera ascendente de causa/efecto, entre sí mismas, construyendo así la matriz de un programa ideal.

No sé si, al lector, esta matriz lo hará llorar, reír, pensar o burlarse de mi candidez. Pero por lo menos desearía que le hiciera pensar. Pensar en sí mismo/a, y sus comportamientos respecto de los/ las otros/as.

Cuadro 10. Programa: El Dr. Pangloss y Karl Kraus escucharon al presidente en Washington

6. REFLEXIONES FINALES 
Debo comenzar por reconocer que para el lector insertarse en los detalles de los dos casos

\begin{tabular}{|c|c|c|c|}
\hline Resumen Narrativo & Indicadores de Logro & Medios de Verificación & \begin{tabular}{|l} 
Supuestos \\
Importantes
\end{tabular} \\
\hline Fin de Programa & & & Sustentabilidad \\
\hline \multirow[t]{3}{*}{$\begin{array}{l}1 \text { Argentina es un país } \\
\text { normal }\end{array}$} & $\begin{array}{l}\text { 1.1 } \\
\text { Se retornan los flujos } \\
\text { inmigratorios }\end{array}$ & 1.1.1 Datos INDEC & \multirow{3}{*}{$\begin{array}{l}1 \text { Se mantienen vigentes } \\
\text { los supuestos de los } \\
\text { niveles anteriores }\end{array}$} \\
\hline & $\begin{array}{ll}1.2 & \begin{array}{l}\text { Se reduce el índice de riesgo } \\
\text { económico }\end{array} \\
\end{array}$ & 1.2.1 Standard\&Poors, etc. & \\
\hline & $\begin{array}{l}\text { 1.3 Se recupera el proceso de } \\
\text { ascenso socioeconómico }\end{array}$ & 1.3.1 Censos Nacionales & \\
\hline Propósito del Programa & & & Propósito A Fin \\
\hline \multirow{9}{*}{$\begin{array}{l}1 \text { El discurso y las } \\
\text { prácticas políticas } \\
\text { son éticas y respetan } \\
\text { la voluntad de las } \\
\text { mayorias y los } \\
\text { derechos de las } \\
\text { minorías }\end{array}$} & $\begin{array}{l}\text { 1.1 El estado es garante de los } \\
\text { derechos y deberes de los } \\
\text { ciudadanos }\end{array}$ & $\begin{array}{l}\text { 1.1.1 Medios de Prensa, encuestas, } \\
\text { Auditoria de la Nación, } \\
\text { Ombudsman }\end{array}$ & \multirow{9}{*}{\begin{tabular}{|l|}
1 Se mantienen vigentes \\
todos los supuestos del \\
nivel anterior \\
2 El propósito del \\
programa es sustentado \\
por los comportamientos \\
ciudadanos y las \\
políticas y \\
procedimientos de la \\
gestión de gobierno
\end{tabular}} \\
\hline & $\begin{array}{l}1.2 \text { Los medios constituyen una } \\
\text { garantía para la sostenibilidad } \\
\text { de la gobernabilidad } \\
\text { democrática }\end{array}$ & $\begin{array}{l}\text { 1.2.1 Medios de Prensa, encuestas, } \\
\text { informes de comisiones del } \\
\text { Congreso, Ombudsman }\end{array}$ & \\
\hline & $\begin{array}{l}\text { 1.3 Las decisiones del Congreso de } \\
\text { la Nación y de los Congresos } \\
\text { Provinciales son transparentes y } \\
\text { equitativas }\end{array}$ & $\begin{array}{l}\text { 1.3.1 Medios de prensa, encuestas, } \\
\text { Auditoria de la Nación, } \\
\text { Ombudsman }\end{array}$ & \\
\hline & $\begin{array}{l}1.4 \text { El Poder Ejecutivo administra el } \\
\text { bien público en función del } \\
\text { bienestar general }\end{array}$ & $\begin{array}{l}\text { 1.4.1 Medios de prensa, encuestas, } \\
\text { Auditoria de la Nación, } \\
\text { Ombudsman }\end{array}$ & \\
\hline & $\begin{array}{l}\text { El Poder Judicial se gana y } \\
\text { mantiene el respeto de todos los } \\
\text { actores sociales y políticos }\end{array}$ & $\begin{array}{l}\text { 1.5.1 Medios de prensa, encuestas, } \\
\text { Auditoria de la Nación, } \\
\text { Ombudsman, informes de } \\
\text { comisiones del Congreso }\end{array}$ & \\
\hline & $\begin{array}{l}1.6 \text { Los partidos políticos no violan } \\
\text { sus propias cartas orgánicas y } \\
\text { canalizan y respetan } \\
\text { democráticamente las opiniones } \\
\text { de sus afiliados y simpatizantes }\end{array}$ & $\begin{array}{l}\text { 1.6.1 Medios de prensa, encuestas, } \\
\text { Auditoria de la Nación, } \\
\text { Ombudsman, informes de } \\
\text { comisiones del Congreso }\end{array}$ & \\
\hline & $\begin{array}{l}1.7 \text { Las organizaciones empresarias } \\
\text { y las grandes empresas no } \\
\text { ejercen ningún poder de lobby } \\
\text { que tuerza a beneficio propio } \\
\text { las decisiones económicas del } \\
\text { Gobierno } \\
\end{array}$ & $\begin{array}{l}\text { 1.7.1 Medios de prensa, encuestas, } \\
\text { Auditoria de la Nación, } \\
\text { Ombudsman, informes de } \\
\text { comisiones del Congreso }\end{array}$ & \\
\hline & \begin{tabular}{|l|}
1.8 Las organizaciones religiosas \\
no invaden con su predica, y \\
posiciones institucionales, el \\
campo especifico de la política \\
partidaria
\end{tabular} & $\begin{array}{l}\text { 1.8.1 Medios de prensa, encuestas, } \\
\text { Auditoria de la Nación, } \\
\text { Ombudsman, informes de } \\
\text { comisiones del Congreso }\end{array}$ & \\
\hline & $\begin{array}{l}\text { 1.9 Las FFAA recuperan el respeto } \\
\text { de la sociedad }\end{array}$ & $\begin{array}{l}\text { 1.9.1 Medios de prensa, encuestas, } \\
\text { Auditoria de la Nación, } \\
\text { Ombudsman, informes de } \\
\text { comisiones del Congreso }\end{array}$ & \\
\hline
\end{tabular}


Una arquitectura del lenguaje aplicada a problemáticas institucionales de gestión pública.

El Plan Fénix y un discurso del presidente Kirchner

\begin{tabular}{|c|c|c|c|}
\hline Resumen Narrativo & Indicadores de Logro & Medios de Verificación & Sup. Importantes \\
\hline & $\begin{array}{l}\text { 1.10 Las Organizaciones Sindicales } \\
\text { actúan en bien de todos los } \\
\text { sectores del trabajo, no entran } \\
\text { en colusión con sectores } \\
\text { empresarios y sostienen } \\
\text { prácticas democráticas } \\
\end{array}$ & $\begin{array}{l}\text { 1.10.1 Medios de prensa, } \\
\text { encuestas, Auditoría de la } \\
\text { Nación, Ombudsman, } \\
\text { informes de comisiones del } \\
\text { Congreso }\end{array}$ & \\
\hline & $\begin{array}{l}\text { 1.11 Los intelectuales y formadores } \\
\text { de opinión ejercen su función } \\
\text { responsablemente }\end{array}$ & $\begin{array}{l}\text { 1.11.1 Medios de prensa, } \\
\text { encuestas, Auditoría de la } \\
\text { Nación, Ombudsman, } \\
\text { informes de comisiones del } \\
\text { Congreso }\end{array}$ & \\
\hline & $\begin{array}{l}\text { 1.12 Las ONG se constituyen en } \\
\text { socios efectivos de las acciones } \\
\text { de gobierno en cuanto } \\
\text { benefician sectores necesitados }\end{array}$ & $\begin{array}{l}\text { 1.12.1 Medios de prensa, } \\
\text { encuestas, Auditoría de la } \\
\text { Nación, Ombudsman, } \\
\text { informes de comisiones del } \\
\text { Congreso }\end{array}$ & \\
\hline & $\begin{array}{l}\text { 1.13 Las organizaciones populares de } \\
\text { base son integradas al proceso } \\
\text { político y socioeconómico de las } \\
\text { políticas públicas }\end{array}$ & $\begin{array}{l}\text { 1.13.1 Medios de prensa, } \\
\text { encuestas, Auditoria de la } \\
\text { Nación, Ombudsman, } \\
\text { informes de comisiones del } \\
\text { Congreso }\end{array}$ & \\
\hline & $\begin{array}{l}1.14 \text { La policia es el garante de la } \\
\text { neutralidad del espacio publico } \\
\text { cívico y de la no violación de } \\
\text { dichas garantías }\end{array}$ & $\begin{array}{l}\text { 1.14.1 Medios de prensa, } \\
\text { encuestas, Auditoría de la } \\
\text { Nación, Ombudsman, } \\
\text { informes de comisiones del } \\
\text { Congreso }\end{array}$ & \\
\hline Componentes del Prog. & & & Componentes a Propósito \\
\hline \multirow{3}{*}{$\begin{array}{l}1 \text { El Estado cumple sus } \\
\text { funciones } \\
\text { constitucionales, } \\
\text { eficiente, eficaz y } \\
\text { efectivamente, y no } \\
\text { es rehén de la } \\
\text { voluntad de ningún } \\
\text { grupo de intereses } \\
\text { particulares, } \\
\text { nacionales o } \\
\text { extranjeros }\end{array}$} & \begin{tabular}{|l}
1.1 El pueblo (del Preámbulo de \\
la Constitución) recibe los \\
recursos necesarios para \\
cubrir sus necesidades \\
vitales en salud, nutrición, \\
educación, vivienda, cultura \\
y trabajo \\
\end{tabular} & $\begin{array}{l}\text { 1.1.1 INDEC, Medios de prensa, } \\
\text { encuestas, Auditoría de la } \\
\text { Nación, Ombudsman, } \\
\text { informes de comisiones del } \\
\text { Congreso }\end{array}$ & \multirow{3}{*}{$\begin{array}{l}1 \text { Los comportamientos } \\
\text { individuales y sociales } \\
\text { de los argentinos se } \\
\text { distancian de toda } \\
\text { forma de } \\
\text { aprovechamiento del } \\
\text { poder, prácticas } \\
\text { tramposas y beneficios } \\
\text { espurios. } \\
2 \text { El estado logra poner en } \\
\text { caja la deuda pública } \\
\text { nacional e internacional } \\
\text { y evita presiones } \\
\text { externas sobre los } \\
\text { intereses nacionales en } \\
\text { las políticas } \\
\text { económicas }\end{array}$} \\
\hline & $\begin{array}{l}\text { Todos los ciudadanos/as } \\
\text { pagan impuestos de } \\
\text { acuerdo con su } \\
\text { capacidad, sin privilegios } \\
\text { sectoriales, ni exenciones } \\
\text { inequitativas }\end{array}$ & $\begin{array}{l}\text { 1.2.1 AFIP, Medios de prensa, } \\
\text { encuestas, Auditoría de la } \\
\text { Nación, Ombudsman, } \\
\text { informes de comisiones del } \\
\text { Congreso }\end{array}$ & \\
\hline & $\begin{array}{l}1.3 \text { Todo ciudadano/a es asistido/a } \\
\text { de acuerdo con su necesidad } \\
\text { cuando no se cumplen las } \\
\text { condiciones básicas de una } \\
\text { vida digna para el/ella y sus } \\
\text { dependientes }\end{array}$ & $\begin{array}{l}\text { 1.3.1 INDEC, Medios de prensa, } \\
\text { encuestas, Auditoría de la } \\
\text { Nación, Ombudsman, } \\
\text { informes de comisiones del } \\
\text { Congreso }\end{array}$ & \\
\hline
\end{tabular}

Cuaderno Urbano. Espacio, Cultura, Sociedad - Vol. I5 - N.ํ 15 (Noviembre de 2013)- Pp. 137-191 - ISNN1666-6186 


\begin{tabular}{|c|c|c|c|c|}
\hline Resumen Narrativo & Indi & cadores de Logro & Medios de Verificación & Sup. Importantes \\
\hline Componentes del Prog. & & & & Componentes a Propósito \\
\hline $\begin{array}{l}2 \text { Los medios no } \\
\text { promueven políticas } \\
\text { ni opciones } \\
\text { económicas sin }\end{array}$ & 2.1 & $\begin{array}{l}\text { Todos los medios de prensa } \\
\text { escrita, de radio y visual } \\
\text { declaran públicamente sus } \\
\text { intereses editoriales }\end{array}$ & $\begin{array}{l}\text { 2.1.1 Medios de prensa, encuestas, } \\
\text { Auditoria de la Nación, } \\
\text { Ombudsman, informes de } \\
\text { comisiones del Congreso }\end{array}$ & $\begin{array}{l}3 \text { Las políticas } \\
\text { macroeconómicas } \\
\text { logran iniciar un } \\
\text { proceso de eliminación }\end{array}$ \\
\hline $\begin{array}{l}\text { transparencia pública } \\
\text { de dichos intereses }\end{array}$ & 2.2 & $\begin{array}{l}\text { Todos los intereses de todos } \\
\text { los medios que no violen los } \\
\text { principios de la Constitución } \\
\text { serán protegidos por el estado }\end{array}$ & $\begin{array}{l}\text { 2.2.1 Medios de prensa, encuestas, } \\
\text { Auditoría de la Nación, } \\
\text { Ombudsman, informes de } \\
\text { comisiones del Congreso }\end{array}$ & $\begin{array}{l}\text { de los excesos de } \\
\text { pobreza y de } \\
\text { desempleo } \\
4 \text { La política exterior }\end{array}$ \\
\hline & 2.3 & $\begin{array}{l}\text { Ningún medio distorsiona la } \\
\text { información primaria para servir } \\
\text { intereses sectoriales }\end{array}$ & $\begin{array}{l}\text { 2.3.1 Medios de prensa, encuestas, } \\
\text { Auditoría de la Nación, } \\
\text { Ombudsman, informes de } \\
\text { comisiones del Congreso }\end{array}$ & $\begin{array}{l}\text { privilegia acciones a } \\
\text { través de las Naciones } \\
\text { Unidas } \\
5 \text { La política económica }\end{array}$ \\
\hline & 2.4 & $\begin{array}{l}\text { Existe el derecho a una } \\
\text { información veraz, que tome en } \\
\text { cuenta todas las opiniones y } \\
\text { ofrezca elementos para que los } \\
\text { ciudadanos puedan adoptar } \\
\text { sus propias decisiones }\end{array}$ & $\begin{array}{l}\text { 2.4.1 Medios de prensa, encuestas, } \\
\text { Auditoría de la Nación, } \\
\text { Ombudsman, informes de } \\
\text { comisiones del Congreso }\end{array}$ & $\begin{array}{l}\text { exterior privilegia al } \\
\text { Mercosur y a las } \\
\text { relaciones } \\
\text { comerciales de ALyC } \\
\text { por encima del ALCA } \\
6 \text { Las políticas cambiarias }\end{array}$ \\
\hline \begin{tabular}{|l}
3 El Congreso es \\
responsable y refleja \\
los deseos de los \\
electores no los de
\end{tabular} & 3.1 & $\begin{array}{l}\text { Todo Senador y/o Diputado de } \\
\text { la Nación es responsable } \\
\text { íntimamente de su juramento } \\
\text { de asunción }\end{array}$ & $\begin{array}{l}\text { 3.1.1 Medios de prensa, encuestas, } \\
\text { Auditoría de la Nación, } \\
\text { Ombudsman, informes de } \\
\text { comisiones del Congreso }\end{array}$ & $\begin{array}{l}\text { y tiscales ellminan el } \\
\text { drenaje impropio de } \\
\text { divisas y fomentan la } \\
\text { inversión legitima }\end{array}$ \\
\hline los lobbies & 3.2 & $\begin{array}{l}\text { Todo Senador y/o Diputado de } \\
\text { la Nación que en su intimidad } \\
\text { sepa que no cumple con tales } \\
\text { principios juramentados } \\
\text { renuncia a su banca por } \\
\text { decisión propia }\end{array}$ & $\begin{array}{l}\text { 3.2.1 Medios de prensa, encuestas, } \\
\text { Auditoria de la Nación, } \\
\text { Ombudsman, informes de } \\
\text { comisiones del Congreso }\end{array}$ & $\begin{array}{l}\text { sanitarias, de salud, } \\
\text { nutrición y vivienda } \\
\text { contribuyen a reducir } \\
\text { las injusticias sociales } \\
\text { imperantes }\end{array}$ \\
\hline & 3.3 & $\begin{array}{l}\text { Todo Senador y/o Diputado de } \\
\text { la Nación siempre representa } \\
\text { los intereses de toda la } \\
\text { población de sus distritos, por } \\
\text { encima de cualquier otro } \\
\text { interés sectorial }\end{array}$ & $\begin{array}{l}\text { 3.3.1 Medios de prensa, encuestas, } \\
\text { Auditoria de la Nación, } \\
\text { Ombudsman, informes de } \\
\text { comisiones del Congreso }\end{array}$ & $\begin{array}{l}\text { no se dirigen contra } \\
\text { grupos poblacionales } \\
\text { específicos }\end{array}$ \\
\hline \begin{tabular}{|l}
4 El Ejecutivo no \\
promueve políticas \\
socialmente \\
divisionistas y busca \\
el bien común
\end{tabular} & 4.1 & $\begin{array}{l}\text { El Presidente, su Gabinete y } \\
\text { otros funcionarios del Poder } \\
\text { Ejecutivo Nacional, se guían } \\
\text { por los principios de la ética en } \\
\text { la administración del patrimonio } \\
\text { público }\end{array}$ & $\begin{array}{l}\text { 4.1.1 Presupuesto nacional, Medios } \\
\text { de prensa, encuestas, } \\
\text { Auditoría de la Nación, } \\
\text { Ombudsman, informes de } \\
\text { comisiones del Congreso }\end{array}$ & \\
\hline & 4.2 & $\begin{array}{l}\text { El Presidente, su Gabinete y } \\
\text { otros funcionarios pertinentes } \\
\text { se guían permanente por los } \\
\text { precipicios de temporalidad en } \\
\text { el mando, de la fiduciaridad en } \\
\text { su administración de los bienes } \\
\text { de la Nación, y de la } \\
\text { transparencia pública de sus } \\
\text { decisiones }\end{array}$ & $\begin{array}{l}\text { 4.2.1 Medios de prensa, encuestas, } \\
\text { Auditoria de la Nación, } \\
\text { Ombudsman, informes de } \\
\text { comisiones del Congreso }\end{array}$ & \\
\hline
\end{tabular}


Una arquitectura del lenguaje aplicada a problemáticas institucionales de gestión pública.

El Plan Fénix y un discurso del presidente Kirchner

\begin{tabular}{|c|c|c|c|c|}
\hline Resumen Narrativo & \multicolumn{2}{|c|}{ Indicadores de Logro } & \multirow[t]{2}{*}{ Medios de Verificación } & Sup. Importantes \\
\hline Componentes del Prog. & & & & Componentes a Propósito \\
\hline & & $\begin{array}{l}\text { El Presidente, su Gabinete y } \\
\text { otros funcionarios pertinentes } \\
\text { no usan sus cargos públicos } \\
\text { para promover intereses de } \\
\text { sector, ni personales }\end{array}$ & $\begin{array}{l}\text { 4.3.1 Medios de prensa, encuestas, } \\
\text { Auditoría de la Nación, } \\
\text { Ombudsman, informes de } \\
\text { comisiones del Congreso }\end{array}$ & \\
\hline \multirow[t]{3}{*}{$\begin{array}{ll}5 & \text { El Poder Judicial es } \\
\text { ético, equitativo y } \\
\text { transparente }\end{array}$} & 5.1 & $\begin{array}{l}\text { Los otros poderes del Estado y } \\
\text { los grupos de intereses de la } \\
\text { sociedad civil respetan la } \\
\text { independencia del Poder } \\
\text { Judicial }\end{array}$ & $\begin{array}{l}\text { 5.1.1 Medios de prensa, encuestas, } \\
\text { Auditoría de la Nación, } \\
\text { Ombudsman, informes de } \\
\text { comisiones del Congreso }\end{array}$ & \\
\hline & 5.2 & $\begin{array}{l}\text { El Poder Judicial se respeta a sí } \\
\text { mismo y a las leyes de la } \\
\text { Nación }\end{array}$ & $\begin{array}{l}\text { 5.2.1 Medios de prensa, encuestas, } \\
\text { Auditoria de la Nación, } \\
\text { Ombudsman, informes de } \\
\text { comisiones del Congreso }\end{array}$ & \\
\hline & 5.3 & $\begin{array}{l}\text { El Art. } 110 \text { de la Constitución y } \\
\text { otros artículos pertinentes de la } \\
\text { Constitución sobre la ética del } \\
\text { Poder Judicial son innecesarios }\end{array}$ & $\begin{array}{l}\text { 5.3.1 Medios de prensa, encuestas, } \\
\text { Auditoria de la Nación, } \\
\text { Ombudsman, informes de } \\
\text { comisiones del Congreso }\end{array}$ & \\
\hline \multirow[t]{4}{*}{$\begin{array}{l}6 \text { Los partidos políticos } \\
\text { actúan solo en el } \\
\text { interés del pueblo } \\
\text { (del Preámbulo de la } \\
\text { Constitución) }\end{array}$} & 6.1 & $\begin{array}{l}\text { Los dirigentes políticos no } \\
\text { promueven enmiendas } \\
\text { constitucionales nacionales o } \\
\text { provinciales para asegurar su } \\
\text { continuidad como } \\
\text { gobernantes, ni ninguna otra } \\
\text { acción legislativa cuyo único } \\
\text { objeto es el beneficio propio } \\
\text { y/o partidario }\end{array}$ & $\begin{array}{l}\text { 6.1.1 Medios de prensa, encuestas, } \\
\text { Auditoría de la Nación, } \\
\text { Ombudsman, informes de } \\
\text { comisiones del Congreso }\end{array}$ & \\
\hline & 6.2 & $\begin{array}{l}\text { Los dirigentes políticos no } \\
\text { utilizan las estructuras } \\
\text { partidarias como instrumentos } \\
\text { de prácticas colusivas, } \\
\text { prebendarias ni nepóticas }\end{array}$ & $\begin{array}{l}\text { 6.2.1 Medios de prensa, encuestas, } \\
\text { Auditoría de la Nación, } \\
\text { Ombudsman, informes de } \\
\text { comisiones del Congreso }\end{array}$ & \\
\hline & 6.3 & $\begin{array}{l}\text { Los dirigentes políticos no } \\
\text { representan intereses de } \\
\text { sectores empresarios, } \\
\text { religiosos, sindicales, } \\
\text { culturales que violan la } \\
\text { Constitución e implican un } \\
\text { asalto al Estado }\end{array}$ & $\begin{array}{l}\text { 6.3.1 Medios de prensa, encuestas, } \\
\text { Auditoría de la Nación, } \\
\text { Ombudsman, informes de } \\
\text { comisiones del Congreso }\end{array}$ & \\
\hline & 6.4 & $\begin{array}{l}\text { Los dirigentes políticos } \\
\text { practican pedagogía política y } \\
\text { contribuyen a erradicar toda } \\
\text { practica tendiente al abuso de } \\
\text { la desinformación ciudadana }\end{array}$ & $\begin{array}{l}\text { 6.4.1 Medios de prensa, encuestas, } \\
\text { Auditoría de la Nación, } \\
\text { Ombudsman, informes de } \\
\text { comisiones del Congreso }\end{array}$ & \\
\hline
\end{tabular}




\begin{tabular}{|c|c|c|c|c|}
\hline Resumen Narrativo & Indi & cadores de Logro & Medios de Verificación & Sup. Importantes \\
\hline Componentes del Prog. & & & & Componentes a Propósito \\
\hline $\begin{array}{|ll|}7 & \text { Los grupos de } \\
& \text { intereses } \\
& \text { empresarios no } \\
& \text { intervienen en las } \\
& \text { decisiones del }\end{array}$ & 7.1 & $\begin{array}{l}\text { No especulan en contra de la } \\
\text { moneda nacional, fiel del } \\
\text { trabajo del pueblo }\end{array}$ & $\begin{array}{l}\text { 7.1.1 Medios de prensa, } \\
\text { encuestas, Auditoría de la } \\
\text { Nación, Ombudsman, } \\
\text { informes de comisiones del } \\
\text { Congreso }\end{array}$ & \\
\hline $\begin{array}{l}\text { estado para generar } \\
\text { ventajas políticas de } \\
\text { mercado }\end{array}$ & 7.2 & $\begin{array}{l}\text { No ejercen presiones directas, } \\
\text { nacionales o extranacionales, } \\
\text { sobre los poderes del Estado } \\
\text { para obtener plusganancias } \\
\text { que excedan las reglas del } \\
\text { mercado }\end{array}$ & $\begin{array}{l}\text { 7.2.1 Medios de prensa, } \\
\text { encuestas, Auditoría de la } \\
\text { Nación, Ombudsman, } \\
\text { informes de Ombudsman, } \\
\text { informes de comisiones del } \\
\text { Congreso }\end{array}$ & \\
\hline & 7.3 & $\begin{array}{l}\text { No crean condiciones } \\
\text { monopólicas que tiendan a } \\
\text { generar plusganacias que } \\
\text { excedan el normal juego de la } \\
\text { competencia }\end{array}$ & $\begin{array}{l}\text { 7.3.1 Medios de prensa, } \\
\text { encuestas, Auditoría de la } \\
\text { Nación, Ombudsman, } \\
\text { informes de comisiones del } \\
\text { Congreso }\end{array}$ & \\
\hline & 7.4 & $\begin{array}{l}\text { Toda empresa, } \\
\text { independientemente del origen } \\
\text { de sus capitales, opera dentro } \\
\text { de las reglas de juego } \\
\text { macroeconómicas fijadas por } \\
\text { la legislación argentina }\end{array}$ & $\begin{array}{l}\text { 7.4.1 Medios de prensa, } \\
\text { encuestas, Auditoría de la } \\
\text { Nación, Ombudsman, } \\
\text { informes de comisiones del } \\
\text { Congreso }\end{array}$ & \\
\hline \begin{tabular}{|ll}
8 La Religión se atiene \\
al espiritu y no \\
interviene en \\
opciones de la vida \\
terrenal, sobre todo
\end{tabular} & 8.1 & $\begin{array}{l}\text { Toda institución religiosa } \\
\text { respeta la voluntad política del } \\
\text { pueblo expresada en las } \\
\text { urnas }\end{array}$ & $\begin{array}{l}\text { 8.1.1 Medios de prensa, } \\
\text { encuestas, Auditoría de la } \\
\text { Nación, Ombudsman, } \\
\text { informes de comisiones del } \\
\text { Congreso }\end{array}$ & \\
\hline $\begin{array}{l}\text { cuando estas violan } \\
\text { las garantías } \\
\text { constitucionales }\end{array}$ & 8.2 & $\begin{array}{l}\text { Toda institución religiosa se } \\
\text { abstiene de influir en el curso } \\
\text { de los eventos políticos en } \\
\text { curso }\end{array}$ & $\begin{array}{l}\text { 8.2.1 Medios de prensa, } \\
\text { encuestas, Auditoría de la } \\
\text { Nación, Ombudsman, } \\
\text { informes de comisiones del } \\
\text { Congreso }\end{array}$ & \\
\hline & 8.3 & $\begin{array}{l}\text { Toda institución religiosa se } \\
\text { abstiene de utilizar argumentos } \\
\text { de conciencia para influir } \\
\text { sobre y/o torcer el rumbo de } \\
\text { políticas públicas de salud, } \\
\text { educación, vínculo civil y } \\
\text { orientación cultural }\end{array}$ & $\begin{array}{l}\text { 8.3.1 Medios de prensa, } \\
\text { encuestas, Auditoría de la } \\
\text { Nación, Ombudsman, } \\
\text { informes de comisiones del } \\
\text { Congreso }\end{array}$ & \\
\hline $\begin{array}{ll}9 \text { Las FFAA, respetan } \\
\text { a la Constitución y } \\
\text { son honorables } \\
\text { éticamente por sobre } \\
\text { todo otro valor }\end{array}$ & 9.1 & $\begin{array}{l}\text { Los miembros de las FFAA } \\
\text { respetan la Constitución no } \\
\text { solo en su letra sino en su } \\
\text { espíritu, y se abstienen de la } \\
\text { formulación de toda opinión } \\
\text { que viole la integridad del } \\
\text { proceso político }\end{array}$ & $\begin{array}{l}\text { 9.1.1 Medios de prensa, } \\
\text { encuestas, Auditoria de la } \\
\text { Nación, Ombudsman, } \\
\text { informes de comisiones del } \\
\text { Congreso }\end{array}$ & \\
\hline & 9.2 & $\begin{array}{l}\text { Los miembros de las FFAA no } \\
\text { solo respetan las RRMM en su } \\
\text { forma, sino además en su } \\
\text { espíritu, practicando } \\
\text { honorablemente su vela de } \\
\text { armas para la seguridad del } \\
\text { pueblo }\end{array}$ & $\begin{array}{l}\text { 9.2.1 Medios de prensa, } \\
\text { encuestas, Auditoría de la } \\
\text { Nación, Ombudsman, } \\
\text { informes de comisiones del } \\
\text { Congreso }\end{array}$ & \\
\hline
\end{tabular}


Una arquitectura del lenguaje aplicada a problemáticas institucionales de gestión pública.

El Plan Fénix y un discurso del presidente Kirchner

\begin{tabular}{|c|c|c|c|}
\hline Resumen Narrativo & Indicadores de Logro & Medios de Verificación & Sup. Importantes \\
\hline Componentes del Prog. & & & Componentes a Propósito \\
\hline \multirow[t]{3}{*}{$\begin{array}{l}10 \text { Las Organizaciones } \\
\text { Sindicales son } \\
\text { democráticas y } \\
\text { participativas y } \\
\text { representan los } \\
\text { intereses de sus } \\
\text { afiliados }\end{array}$} & $\begin{array}{l}\text { 10.1 Ningún dirigente sindical se } \\
\text { beneficia personalmente en sus } \\
\text { bienes pecuniarios como } \\
\text { consecuencia de la influencia } \\
\text { que le otorga su } \\
\text { representatividad }\end{array}$ & $\begin{array}{l}\text { 10.1.1 Medios de prensa, } \\
\text { encuestas, Auditoría de la } \\
\text { Nación, Ombudsman, } \\
\text { informes de comisiones del } \\
\text { Congreso }\end{array}$ & \\
\hline & $\begin{array}{l}\text { 10.2 Todas las organizaciones } \\
\text { sindicales son organizadas } \\
\text { democráticamente siguiendo las } \\
\text { mismas prácticas electorales que } \\
\text { las que establece la Constitución } \\
\text { para las elecciones de los } \\
\text { representantes del pueblo } \\
\end{array}$ & $\begin{array}{l}\text { 10.2.1 Medios de prensa, } \\
\text { encuestas, Auditoría de la } \\
\text { Nación, Auditoría de la } \\
\text { Nación, Ombudsman, } \\
\text { informes de comisiones del } \\
\text { Congreso }\end{array}$ & \\
\hline & $\begin{array}{l}\text { 10.3 Ninguna organización sindical } \\
\text { abusa de sus derechos } \\
\text { legítimos con fines } \\
\text { exclusivamente políticos } \\
\text { partidistas }\end{array}$ & $\begin{array}{l}\text { 10.3.1 Medios de prensa, } \\
\text { encuestas, Auditoría de la } \\
\text { Nación, Ombudsman, } \\
\text { informes de comisiones del } \\
\text { Congreso }\end{array}$ & \\
\hline \multirow{2}{*}{$\begin{array}{l}11 \text { La inteligentsia } \\
\text { acepta el principio de } \\
\text { los límites de toda } \\
\text { presunta verdad y se } \\
\text { rige por los principios } \\
\text { de la prueba y la } \\
\text { refutación, dirigiendo } \\
\text { su vocación al } \\
\text { servicio de los } \\
\text { intereses del pueblo }\end{array}$} & $\begin{array}{l}\text { 11.1 Ningún intelectual o formador de } \\
\text { opinión abusa de prebendas } \\
\text { públicas, circunstancias } \\
\text { políticas u otra condición } \\
\text { personal no inherente a la ética } \\
\text { del pensamiento, para avalar, } \\
\text { sustentar y/o promover su ideas } \\
\end{array}$ & $\begin{array}{l}\text { 11.1.1 Medios de prensa, } \\
\text { encuestas, Auditoría de la } \\
\text { Nación, Ombudsman, } \\
\text { informes de comisiones del } \\
\text { Congreso }\end{array}$ & \\
\hline & $\begin{array}{l}\text { 11.2 Ningún intelectual o formador de } \\
\text { opinión abusa de su } \\
\text { conocimiento para diseminar su } \\
\text { pensamiento de tal manera que } \\
\text { directa o indirectamente viole } \\
\text { los principios de la Constitución }\end{array}$ & $\begin{array}{l}\text { 11.2.1 Medios de prensa, } \\
\text { encuestas, Auditoría de la } \\
\text { Nación, Ombudsman, } \\
\text { informes de comisiones del } \\
\text { Congreso }\end{array}$ & \\
\hline \multirow{3}{*}{$\begin{array}{l}12 \text { Las organizaciones } \\
\text { no gubernamentales } \\
\text { no deben representar } \\
\text { ni promover intereses } \\
\text { sectoriales que no } \\
\text { hagan al bien común } \\
\text { ni se opongan a las } \\
\text { políticas públicas } \\
\text { decididas } \\
\text { electoralmente }\end{array}$} & $\begin{array}{l}12.1 \text { Las ONG no abusan de sus } \\
\text { acciones para promover } \\
\text { objetivos culturales, religiosos, } \\
\text { económicos, sociales o políticos } \\
\text { ajenos a su misión no } \\
\text { gubernamental } \\
\end{array}$ & $\begin{array}{l}\text { 12.1.1 Medios de prensa, } \\
\text { encuestas, Auditoría de la } \\
\text { Nación, Ombudsman, } \\
\text { informes de comisiones del } \\
\text { Congreso }\end{array}$ & \\
\hline & $\begin{array}{l}\text { 12.2 Las ONG no utilizan su función } \\
\text { de asistencia social como } \\
\text { medio para ejercer proselitismo } \\
\text { de cualquier índole }\end{array}$ & $\begin{array}{l}\text { 12.2.1 Medios de prensa, } \\
\text { encuestas, Auditoría de la } \\
\text { Nación, Ombudsman, } \\
\text { informes de comisiones del } \\
\text { Congreso }\end{array}$ & \\
\hline & $\begin{array}{l}12.3 \text { Las ONG no promueven la } \\
\text { continuidad de sus acciones más } \\
\text { allá del cumplimiento de los } \\
\text { objetivos establecidos en los } \\
\text { acuerdos o contratos de } \\
\text { provisión de bienes y/o servicios. }\end{array}$ & $\begin{array}{l}\text { 12.3.1 Medios de prensa, } \\
\text { encuestas, Auditoría de la } \\
\text { Nación, Ombudsman, } \\
\text { informes de comisiones del } \\
\text { Congreso }\end{array}$ & \\
\hline
\end{tabular}

Cuaderno Urbano. Espacio, Cultura, Sociedad - Vol. I5 - N.ํ 15 (Noviembre de 2013)- Pp. 137-191 - ISNN1666-6186 


\begin{tabular}{|c|c|c|c|}
\hline Resumen Narrativo & Indicadores de Logro & Medios de Verificación & Sup. Importantes \\
\hline Componentes del Prog. & & & Componentes a Propósito \\
\hline \multirow{3}{*}{$\begin{array}{l}13 \text { Las organizaciones } \\
\text { populares ejercen su } \\
\text { derecho de } \\
\text { representar sus } \\
\text { agravios ante los } \\
\text { poderes políticos sin } \\
\text { coerción de ningún } \\
\text { tipo }\end{array}$} & $\begin{array}{l}\text { 13.1 El estado reconocerá } \\
\text { institucionalmente los nuevos } \\
\text { fenómenos de organización } \\
\text { popular emergentes de la crisis }\end{array}$ & $\begin{array}{l}\text { 13.3.1 Medios de prensa, } \\
\text { encuestas, Auditoría de la } \\
\text { Nación, Ombudsman, } \\
\text { informes de comisiones del } \\
\text { Congreso }\end{array}$ & \\
\hline & \begin{tabular}{|l|} 
13.2 El Gobierno Nacional y los \\
Gobiernos Provinciales no \\
utilizarán a estas organizaciones \\
populares con fines políticos \\
partidarios \\
\end{tabular} & $\begin{array}{l}\text { 13.2.1 Medios de prensa, } \\
\text { encuestas, Auditoría de la } \\
\text { Nación, Ombudsman, } \\
\text { informes de comisiones del } \\
\text { Congreso }\end{array}$ & \\
\hline & $\begin{array}{l}\text { 13.3 Los dirigentes de estas } \\
\text { organizaciones actuarán solo en } \\
\text { pos del interés de sus miembros } \\
\text { y/o simpatizantes }\end{array}$ & $\begin{array}{l}\text { 13.3.1 Medios de prensa, } \\
\text { encuestas, Auditoría de la } \\
\text { Nación, Ombudsman, } \\
\text { informes de comisiones del } \\
\text { Congreso }\end{array}$ & \\
\hline \multirow[t]{3}{*}{$\begin{array}{l}14 \text { La policía es bien } \\
\text { paga, bien entrenada } \\
\text { y protege a los } \\
\text { ciudadanos de la } \\
\text { violación de sus } \\
\text { derechos civiles }\end{array}$} & $\begin{array}{l}\text { Todos los ciudadanos confían } \\
\text { en la acción policial }\end{array}$ & $\begin{array}{l}\text { 14.1.1 Medios de prensa, } \\
\text { encuestas, Auditoría de la } \\
\text { Nación, Ombudsman, } \\
\text { informes de comisiones del } \\
\text { Congreso }\end{array}$ & \\
\hline & \begin{tabular}{|l|}
14.2 Las fuerzas policiales \\
desarrollan nuevas técnicas y \\
prácticas de acción no invasivas \\
adecuadas a las condiciones de \\
pobreza y pobreza extrema
\end{tabular} & $\begin{array}{l}\text { 14.2.1 Medios de prensa, } \\
\text { encuestas, Auditoría de la } \\
\text { Nación, Ombudsman, } \\
\text { informes de comisiones del } \\
\text { Congreso }\end{array}$ & \\
\hline & \begin{tabular}{|l|}
14.3 Las fuerzas policiales son \\
capacitadas y poseen los \\
medios para actuar \\
afirmativamente en el campo de \\
los delitos de cuello blanco, y el \\
e-delito. \\
\end{tabular} & $\begin{array}{l}\text { 14.3.1 Medios de prensa, } \\
\text { encuestas, Auditoría de la } \\
\text { Nación, Ombudsman, } \\
\text { informes de comisiones del } \\
\text { Congreso }\end{array}$ & \\
\hline Actividades del Prog. & & & $\begin{array}{l}\text { Actividades a } \\
\text { Componentes }\end{array}$ \\
\hline 1.1 & \begin{tabular}{|l|}
1.1 .1 \\
\end{tabular} & 1.1.1.1 & 1 \\
\hline $\begin{array}{l}\text { Todas serán colocadas } \\
\text { por cada sujeto (hasta } \\
\text { 14.3) }\end{array}$ & & & \\
\hline
\end{tabular}


que he expuesto puede ser laborioso y hasta de difícil comprensión. Quizás por ello en la mayoría de las instituciones que utilizan hoy el marco lógico como instrumento de diseño y evaluación de proyectos frecuentemente los aplican mal, con diferentes definiciones de los cuatro niveles ascendentes del marco lógico (actividades $>$ productos resultantes $>$ resultados del uso de los productos $>$ cambios sociales y económicos emergentes de esos usos). Ricardo Wilson Grau, en un documento de 2008, refiriéndose a esta Torre de Babel en diferentes organismos internacionales se queja de las definiciones conflictivas del uso de la terminología del Marco Lógico. Wilson Grau no lo menciona, pero yo concluyo que estas instituciones confunden la tabla de ajedrez con saber las reglas que determinan sus piezas y el uso de esas piezas, es decir, las reglas del juego.

Es por esta razón que vuelvo al punto de partida e insisto en que el marco lógico se aplica mal, ya que se lo usa como una tabla, que acompaña usualmente a la tabla de costos, y no como una matriz. Se definen mal los contenidos de sus filas y columnas, no se efectúa un análisis de involucrados ni se establece en consecuencia un árbol de problemas y soluciones, que es la llave para comenzar el proceso deductivo del diseño de un proyecto o programa.

No se entiende que cada grupo de involucrados llega a la mesa de negociaciones (si es que la arrogancia de las instituciones o de los académicos ilustrados se los permite) con un juego de lenguaje diferente, el cual no puede ser subsumido en el lenguaje dominante de las instituciones proyectoras, generalmente el de sus economistas, sin resultados procrustianos.

No se entiende, o no se quiere entender, como sugirió BAKHTIN, que el diálogo entre juegos de lenguaje es lo único que nos deja pasar de la heteroglosia a la homoglosia, y menos se entiende como sugirió Volosinov, hace más de 70 años, que las instituciones o ciertos bloques profesionales con "llegada" al poder o con su propio poder académico usan al lenguaje como sistema principal de poder. Hablan de participación y democracia, pero no la practican en el seno de la generación de sus productos para esa democracia.

Sin entender, ni queriendo entender estas dimensiones dialógicas, las instituciones internacionales multilaterales y nacionales involucradas en el financiamiento de productos económicos, sociales y culturales, se enfrascan en la discusión de cómo nombran las columnas y las filas del ML y se olvidan del entorno del marco lógico, que lo transforma en un instrumento dialógico, porque ello les permite la mentira antiespinoziana, la apertura a la antiética en sus "proyectos de desarrollo".

Espero que a través de los casos que he presentado hayan quedado más claros algunos de los principios que requiere una práctica diferente de generar, financiar y ejecutar acciones institucionales de gobierno. 